\title{
A bibliometric analysis of the highest cited and highest category normalised articles in radiological literature from 2009-2019.
}

\author{
McKay Parry, Nicholas ${ }^{\mathrm{a}, \mathrm{b} *}$, Rich, Justin ${ }^{\mathrm{a}}$, Erian, Michael ${ }^{\mathrm{c}}$, Thomas Lloyd ${ }^{\mathrm{d}, \mathrm{e}}$
}

${ }^{a}$ Resident Medical Officer, Medical Imaging Department, Logan Hospital, Brisbane, Australia;

${ }^{b}$ Associate Lecturer, Department of Medicine, Griffith University, Gold Coast, Australia;

${ }^{c}$ Resident Medical Officer, Department of Orthopaedics, Queen Elizabeth II Jubilee

Hospital, Brisbane, Australia

${ }^{d}$ Senior Staff Specialist, Department of Diagnostic Radiology, Princess Alexandra Hospital,

Brisbane, Australia

e Adjunct Professor, Faculty of Health, Queensland University of Technology, Brisbane,

Australia

Please address all correspondence to:

Dr. Nicholas McKay Parry

Email: Nicholas.mckayparry@health.qld.gov.au

Medical Imaging Department, Logan Hospital

Armstrong Rd \& Loganlea Rd, Meadowbrook QLD 4131

Tel.: +61432 846398 ;

\section{Conflict of Interest Statement}

Each author certifies that he has no commercial, academic or other associations that might pose a conflict of interest in connection with the submitted article.

\section{Keywords}

Radiology, bibliometrics, citation analysis, category normalised citation impact, CNCI, medical imaging. 
medRxiv preprint doi: https://doi.org/10.1101/2020.11.14.20231944; this version posted November 17, 2020. The copyright holder for this preprint (which was not certified by peer review) is the author/funder, who has granted medRxiv a license to display the preprint in It is made available under a CC-BY-NC-ND 4.0 International license .

\begin{abstract}
Rationale and Objective; Citation-based metrics are frequently used to evaluate the academic performance of a publication. One such metric is the number of citations an article receives, however this is not an infallible index. To account for biases of this metric the categorynormalised citation index (CNCI), termed 'impact', may be used. Here the 100 highest-cited and highest-CNCI articles in radiological literature, from $2009-2019$ is performed.
\end{abstract}

Materials and Methods; The Web of Science Core Collection and InCites (Clarivate Analytics) databases were accessed for the citations and CNCI values for articles published in the 186 journals with category "radiology, nuclear medicine, and medical imaging" between 2009 and 2019. The top 100 articles with the highest citation count and highest CNCI values were collected. Article parameters were analysed including title, year of publication, citation count, CNCI, field of study and modality studied were analysed.

Results: Fifty-three articles were common to both lists. Neuroradiology was the most prevalent subspecialty studied in both the highest-cited $(n=68)$ and highest-impact $(n=41)$ lists, respectively. The most frequently utilised imaging modality was magnetic resonance imaging $(n=64$ and 40). The highest-CNCI articles demonstrated greater variability and distribution across subspecialties, imaging modalities and year of publication when compared to the highest-cited list.

Conclusion: The use of normalised bibliometric analysis tools may remove bias when evaluating research and better demonstrate the breadth of research activity. Use of these tools may provide a more robust and contemporaneous review of the landscape of research within a field. 


\section{The 100 highest-cited and highest-impact articles in radiological literature; 2009 to 2019.}

\subsection{Introduction}

Bibliometric analysis is an established paradigm to compare the performance of academic output (1). One of the most common measures of performance is the raw citation count of an article - with the greater citation count reflecting greater significance. However, this metric fails to factor in the discipline of interest, age of publication and document type making it difficult to compare across academic disciplines (or sub-disciplines) as well as temporally and typically favours popularist topics. Other evaluative metrics exist to account for these biases and limitations, including the Category Normalised Citation Index (CNCI) $(2,3)$. The CNCI is calculated by ratio of the actual count of citing items divided by the expected citation count for documents within the same field, year and type of article. Therefore, the CNCI normalises the citation count and expresses how much impact it has within its field. A CNCI of 2, for example, means the publication had twice as many citations as expected an article with a CNCI of 1 . This creates a valuable measure of an articles significance which allows for comparison of articles in previous domains.

Bibliometric analyses is an increasingly popular method of defining significant reserch across medical literature (4-6). It serves to provide stakeholders (practitioners, researchers, trainees, etc) insights into the research . Citation and bibliometric analysis has been performed in the past within the radiological literature (7-11). However no studies, to the authors knowledge, has performed a category normalised citation index in radiological literature. By performing a bibliometric analysis with a normalised metric trends and impactful articles from less cited fields of research may emerge for interested stakeholders. 
medRxiv preprint doi: https://doi.org/10.1101/2020.11.14.20231944; this version posted November 17, 2020. The copyright holder for this preprint (which was not certified by peer review) is the author/funder, who has granted medRxiv a license to display the preprint in It is made available under a CC-BY-NC-ND 4.0 International license.

Our study aimed to determine the characteristics and trends of the 100 highest-cited and highest-CNCI' articles in medical imaging literature between 2009 and 2019 within the Web of Science (WOS) database. In doing so both the highest-cited and highest-CNCI works in radiological journals are available to provide insight into contemporary radiological research. In addition this research serves to illustrate the utility of normalised bibliometrics. 
medRxiv preprint doi: https://doi.org/10.1101/2020.11.14.20231944; this version posted November 17, 2020. The copyright holder for this preprint (which was not certified by peer review) is the author/funder, who has granted medRxiv a license to display the preprint in It is made available under a CC-BY-NC-ND 4.0 International license .

\subsection{Materials and Methods}

In July 2020 the Web of Science (WOS) Core Collection (Clarivate Analytics) database was accessed to extract 186 journals with WOS category "Radiology, Nuclear Medicine \& Medical Imaging" within the Science Citation Index Expanded (SCIE) and Emerging Source Citation Index (ESCI) respectively. The WOS database was limited to searches of these journals and the 100 articles with greatest number of citations between 2009 and 2019 , inclusive, were recorded. Similarly, InCites (Clarivate Analytics) was accessed to extract the 100 articles with highest-CNCI. Articles excluded include those classified as primarily pertinent to radiation oncology and of the type "bibliographic, meeting article, preceding paper, news item, correction, letters to editor" were excluded due to biases in these article types which inflate their CNCI.

Each article within the highest-cited and highest-impact (CNCI) list were reviewed by two authors for categorisation. Following the template of Lim et al (10) and Brinkiki et al (11), data was collected on the following variables; (a) article demographics (journal name, impact factor of the journal, year of publication); (b) radiologic subspecialty (neuroradiology/head and neck [including studies related to fMRI], abdominal, breast, cardiac, respiratory, genitourinary [including retroperitoneum and obstetrics], musculoskeletal, paediatric, vascular/interventional, nuclear medicine, imaging safety or miscellaneous [not conforming to aforementioned categories including whole-body imaging, radiomics, physics/image processing and basic science]) and (c) radiographic technique/modality (conventional radiography, ultrasound, computed tomography (CT), magnetic resonance imaging (MRI), angiography, mammography, interventional, nuclear imaging [including PET, SPECT, PET/CT and PET/MRI ], mixed and other [not conforming to above including image analysis 
medRxiv preprint doi: https://doi.org/10.1101/2020.11.14.20231944; this version posted November 17, 2020. The copyright holder for this preprint (which was not certified by peer review) is the author/funder, who has granted medRxiv a license to display the preprint in It is made available under a CC-BY-NC-ND 4.0 International license

tools]). Noting the radiologic subspeciality and radiographic modality are mutually exclusive variables.

Intersection over union calculations were performed to address similarity of articles via the Jaccard index (12). Analysis was performed using numerical computing environment MATLAB (R2018b; Mathworks, Massachusetts, USA). 
medRxiv preprint doi: https://doi.org/10.1101/2020.11.14.20231944; this version posted November $17,2020$. The copyright holder for this preprint (which was not certified by peer review) is the author/funder, who has granted medRxiv a license to display the preprint in It is made available under a CC-BY-NC-ND 4.0 International license .

\subsection{Results}

The 100 highest-cited works of 2009-2019 in radiological literature are presented in Table 1. The citation median was 694 (range 506 to 4008) and CNCI median 28.9 (range 9.31 to 198.8 ) and median year of publication 2011.

The 100 highest-CNCI works between 2009-2019 are presented in Table 2. The citation median was 533 (range 42 to 4008) and CNCI median was 37.9 (range 27 to 198.8), and median year of publication 2013. Figure 1 presents a box and whisker plot to compare the distribution of articles between the two lists in terms of their raw citation count and CNCI. Table 3 presents the number of articles within each list published for a given year. Fifty-three articles were common to both lists with a Jaccard similarity index of $36 \%$, demonstrating significant differences (low overlap) between the elements of each list.

The highest-cited works appeared across 23 different journals while the 100 highestCNCI across 24 (Table 4). The journal with greatest number of highest-cited and highest-CNCI articles was NeuroImage with 51 and 30 respectively. The next highest contributor in the mostcited list was IEEE Transactions on Medical Imaging $(\mathrm{n}=6)$, Human Brain Mapping $(\mathrm{n}=5)$, and Magnetic Resonance in Imaging $(\mathrm{n}=5)$. Within the highest-CNCI list different journals showed higher contributors of articles with Radiology $(\mathrm{n}=13)$, IEEE Transactions on Medical Imaging $(\mathrm{n}=11)$, and European Journal of Nuclear Medicine and Molecular Imaging $(\mathrm{n}=8)$ contributing the most.

The most frequent referenced subspeciality and modality was common to both the highest-citation and highest-CNCI list. These were neuroradiology (68 and 41 articles) and magnetic resonance imaging (64 and 40 articles), nothing these are not independent variables with MRI the primarily modality in neuroradiological imaging. Sub-analysis revealed that of 
medRxiv preprint doi: https://doi.org/10.1101/2020.11.14.20231944; this version posted November 17, 2020. The copyright holder for this preprint (which was not certified by peer review) is the author/funder, who has granted medRxiv a license to display the preprint in It is made available under a CC-BY-NC-ND 4.0 International license .

the 68 and 41 neuroradiology articles within each list, 55\% and 58\% of each pertained to development or evaluation of computer science/mathematical/image processing techniques on neuroradiological data rather than primary clinical radiological research.

Articles conforming to 'miscellaneous' (15 \& 21 articles) and imaging 'safety' (5, 6 articles respectively) were the next most common radiological domain studied for both list. The highest-CNCI articles demonstrated a greater variance in modalities studied in comparison to the highest-citation list. In particular, a greater number of studies with primary modality of nuclear medicine and CT were present in the highest-CNCI list. A breakdown of subspecialty and modality is given in Table 5 .

\subsection{Discussion}

Within this study the first, to the authors knowledge, bibliometric analysis of radiological articles based on highest CNCI was performed. This was done alongside an analysis of the 100 highest raw citation count articles for the past decade of radiological literature. Similar bibliometric studies have been performed in the past, including analysis on the highest cited medical imaging literature ever published $(7,10,11,13,14)$. However, with the ever-growing volume of academic publications, contemporaneous re-evaluation of emerging trends and topics, with alternative metrics, is beneficial to inform various stakeholders. These stakeholders include (but are not limited to) practicing and trainee radiologists, physicists/mathematicians, computer scientists, radiographers, and nonradiologist clinicians.

The decade of 2009 - 2019 highest-cited articles had characteristics similar to previous studies $(7,8,11)$. In particular neuroradiology and magnetic resonance imaging were highly prevalent topics of research. An explanation for this is proposed by Brinkiji et al. in which they discuss how there is a variety of stakeholders from various research fields publishing on this 
medRxiv preprint doi: https://doi.org/10.1101/2020.11.14.20231944; this version posted November $17,2020$. The copyright holder for this preprint (which was not certified by peer review) is the author/funder, who has granted medRxiv a license to display the preprint in It is made available under a CC-BY-NC-ND 4.0 International license .

topic resulting in a skewed representation of neuroradiologically inclined research (11). The populist nature of these fields results in an inherent bias in the number of citations a publication with garner. The analysis presented here of the temporal course of the highest-cited works show a predilection for older articles, median year of 2011, with most recent work appearing in the list published in 2017. This highlights another bias in relying on raw citation count as a metric of academic performance. In particular, older articles have a greater amount of time to accrue citations when compared to contemporary works. The CNCI of these articles show a broad range with a median of CNCI of 28.9. Whilst these articles show a lower median/average CNCI than the highest-CNCI list it is important to note that even the article with the lowest CNCI (9.3) still garners $9.3 \mathrm{x}$ as many citations as expected for an article of same type and same year of publication.

The highest-CNCI list, in comparison, shows greater diversity in its citation range, subspeciality referenced and imaging modality and differences in temporal trends. Objectively, the lists have a low similarity score with Jaccard index of 33\% resenting significant differences in their contents. Whilst the most dominant subspeciality and modality remains neuroradiology and magnetic resonance imaging they it is a smaller comparison to the highest cited list. With respect to subspeciality, there is a greater spread of research areas contained within the list. In particular, articles related to nuclear imaging, respiratory system, and genitourinary systems are more abundant. Further, the highest-CNCI articles have a greater diversity in other imaging modalities, including a small number of articles based on conventional radiography and breast imaging. The emergence of these studies illustrate the utility of normalised bibliometric indices, here the CNCI. In particular, whilst neuroradiology and MR imaging may have the greatest volume of researchers and overlap with computer science, when normalised to their domain of study other fields can be more fairly compared. In addition, temporal citation bias is removed by indexing its performance to the year of publication. This is evidenced by the 
medRxiv preprint doi: https://doi.org/10.1101/2020.11.14.20231944; this version posted November 17, 2020. The copyright holder for this preprint (which was not certified by peer review) is the author/funder, who has granted medRxiv a license to display the preprint in It is made available under a CC-BY-NC-ND 4.0 International license .

even distribution and spread of article publication year in the highest-CNCI articles. As an example, the article "Dual-Energy (Spectral) CT: Applications in Abdominal Imaging” appears in the highest-CNCI list whose subspecialty and modality is not represented well within the highest-cited list. However, spectral imaging is an emerging field of radiology with a great deal of potential and interest to the radiological community at large $(15,16,16,17)$. As such the inherent value in understanding and evaluating articles based on alternative bibliometric values is apparent. One possibility is that by using normalised bibliometric analysis 'classic' or 'seminal' works can be identified or predicted prospectively.

There are limitations of this study. Citation analysis is not a precise science, nor is normalisation with respect to category normalised citation index. Both metrics of interest are inherently biased by self-citation and the so-called 'Bradfords' Law. This law describing the positive feedback mechanism of publishing and referencing from a small variety of journals or authors (18). Further, an articles CNCI may be artificially raised by including it into a category that does not typically garner many publications and rewards recent publications that have been cited. Those with low total citation counts and high CNCI need to be carefully considered as biased. As an example, the rank \#86 article in the highest-impact list has 42 citations, where one would expect only 1.5 citations by now. However, given it has only recently been published it is inappropriate to evaluate the impact of this article purely on its CNCI value as the normalisation process requires an appropriate passage of time. Another limitation is the use of a single database, restricted to journals within the WOS "Radiology, Nuclear Medicine \& Medical Imaging" SCIE and ESCI databases. Therefore, any articles that are radiologically based but published in journals outside those within the WOS database would not be included. This excludes radiology articles that may have been published in journals such as Nature and Science, for example. Further, if analysis were undertaken on different databases (e.g. Google 
medRxiv preprint doi: https://doi.org/10.1101/2020.11.14.20231944; this version posted November 17, 2020. The copyright holder for this preprint (which was not certified by peer review) is the author/funder, who has granted medRxiv a license to display the preprint in It is made available under a CC-BY-NC-ND 4.0 International license .

Scholar, Scopus, etc) the highest-citation results would be expected to differ $(19,20)$. However, the effect of differing databases on CNCI is not clear.

To mitigate and/or review the potential impact of these various limitations future researchers are encouraged to conduct a comparative analyses across all available databases, especially in regards to normalised citation rates. Further, to not exclude high profile radiological articles being excluded, more exhaustive searches for literature could be performed.

\subsection{Conclusions}

In summary, to the authors knowledge the first citation-normalised bibliometric analysis of radiological literature has been performed. This was done alongside a conventional raw citation count analysis over the years 2009 - 2019 in order to investigate the trends and characteristics of the highest-cited and highest-CNCI articles. The results illustrate the ongoing academic output the field of neuroradiology and use magnetic resonance imaging has. The $\mathrm{CNCI}$ analysis produced a list distinctly different from the highest-cited works with a more varied distribution of research subspecialty and imaging modality. This may better represent the current research landscape of radiological research and guide future bibliometric analyses. 
medRxiv preprint doi: https://doi.org/10.1101/2020.11.14.20231944; this version posted November $17,2020$. The copyright holder for this preprint (which was not certified by peer review) is the author/funder, who has granted medRxiv a license to display the preprint in It is made available under a CC-BY-NC-ND 4.0 International license .

\subsection{References}

1. Durieux V, Gevenois PA. Bibliometric Indicators: Quality Measurements of Scientific Publication. Radiology. 2010 Apr 8;255(2):342-51.

2. Bornmann L, Marx W. Methods for the generation of normalized citation impact scores in bibliometrics: Which method best reflects the judgements of experts? J Informetr. 2015 Apr 1;9(2):408-18.

3. Waltman L, van Eck NJ. Source normalized indicators of citation impact: an overview of different approaches and an empirical comparison. Scientometrics. 2013 Sep 1;96(3):699_ 716.

4. Shuaib W, Khan MS, Shahid H, Valdes EA, Alweis R. Bibliometric Analysis of the Top 100 Cited Cardiovascular Articles. Am J Cardiol. 2015 Apr 1;115(7):972-81.

5. Kelly JC, Glynn RW, O'Briain DE, Felle P, McCabe JP. The 100 classic papers of orthopaedic surgery. J Bone Joint Surg Br. 2010 Oct 1;92-B(10):1338-43.

6. Ponce FA, Lozano AM. Highly cited works in neurosurgery. Part I: the 100 top-cited papers in neurosurgical journals: A review. J Neurosurg. 2010 Feb 1;112(2):223-32.

7. Yoon DY, Yun EJ, Ku YJ, Baek S, Lim KJ, Seo YL, et al. Citation Classics in Radiology Journals: The 100 Top-Cited Articles, 1945-2012. Am J Roentgenol. 2013 Sep;201(3):471-81.

8. Pagni M, Khan NR, Cohen HL, Choudhri AF. Highly Cited Works in Radiology: The Top 100 Cited Articles in Radiologic Journals. Acad Radiol. 2014 Aug 1;21(8):1056-66.

9. Crockett MT, Browne RF, MacMahon PJ, Lawler L. 100 classic papers of interventional radiology: A citation analysis. World J Radiol. 2015 Apr 28;7(4):79-86.

10. Lim KJ, Yoon DY, Yun EJ, Seo YL, Baek S, Gu DH, et al. Characteristics and Trends of Radiology Research: A Survey of Original Articles Published in AJR and Radiology between 2001 and 2010. Radiology. 2012 Sep 1;264(3):796-802.

11. Brinjikji W, Klunder A, Kallmes DF. The 100 Most-cited Articles in the Imaging Literature. Radiology. 2013 Oct 1;269(1):272-6.

12. Hamers L. Similarity measures in scientometric research: The Jaccard index versus Salton's cosine formula. Inf Process Manag. 1989;25(3):315-18.

13. Kim HJ, Yoon DY, Kim ES, Lee K, Bae JS, Lee J-H. The 100 most-cited articles in neuroimaging: A bibliometric analysis. NeuroImage. 2016 Oct 1;139:149-56.

14. Shekhani HN, Shariff S, Bhulani N, Khosa F, Hanna TN. Bibliometric Analysis of Manuscript Characteristics That Influence Citations: A Comparison of Six Major Radiology Journals. Am J Roentgenol. 2017 Oct 24;209(6):1191-6.

15. Cicero G, Ascenti G, Albrecht MH, Blandino A, Cavallaro M, D’Angelo T, et al. Extraabdominal dual-energy CT applications: a comprehensive overview. Radiol Med (Torino). 2020 Apr 1;125(4):384-97. 
medRxiv preprint doi: https://doi.org/10.1101/2020.11.14.20231944; this version posted November $17,2020$. The copyright holder for this preprint (which was not certified by peer review) is the author/funder, who has granted medRxiv a license to display the preprint in It is made available under a CC-BY-NC-ND 4.0 International license .

16. Siegel MJ, Ramirez-Giraldo JC. Dual-Energy CT in Children: Imaging Algorithms and Clinical Applications. Radiology. 2019 Mar 26;291(2):286-97.

17. Dual-Energy CT in Emergency Neuroimaging: Added Value and Novel Applications RadioGraphics [Internet]. [cited 2020 Oct 5]. Available from: https://pubs.rsna.org/doi/full/10.1148/rg.2016160069

18. Egghe L. On the classification of the classical bibliometric laws. J Doc. 1988;44(1):53-62.

19. Kulkarni AV, Aziz B, Shams I, Busse JW. Comparisons of citations in Web of Science, Scopus, and Google Scholar for articles published in general medical journals. Jama. 2009;302(10):1092-1096.

20. Li J, Burnham JF, Lemley T, Britton RM. Citation analysis: Comparison of web of science ${ }^{\circledR}$, scopus $^{\mathrm{TM}}$, SciFinder ${ }^{\circledR}$, and google scholar. J Electron Resour Med Libr. 2010;7(3):196-217.

\subsection{Acknowledgements}

The authors thank the input from Dr. Christopher Erian for useful discussion and guidance.

\subsection{Figures \& Table Legends}

Table 1. Top 100 highest-citations articles in radiological literature (2009-2019).

Table 2. Top 100 highest-impact articles in radiological literature $(2009-2019)$.

Table 3. Number of articles per list according to year of publication.

Table 4. Number of articles per list according to publishing journal.

Table 5. Number of articles according to radiological subspecialty and primary modality

Figure 1. Box plot illustrating distribution of number citations (left axis) and category normalised impact factor (right axis) for the highest-cited (grey) and highest-impact (brown) article lists 
medRxiv preprint doi: https://doi.org/10.1101/2020.11.14.20231944; this version posted November 17, 2020. The copyright holder for this preprint (which was not certified by peer review) is the author/funder, who has granted medRxiv a license to display the preprint in It is made available under a CC-BY-NC-ND 4.0 International license .

\subsection{Abbreviations}

\section{CNCI - Category Normalised Citation Index}

WOS - Web of Science

SCIE - Science Citation Index Expanded

ESCI - Emerging Source Citation Index

MR - Magnetic Resonance

\subsection{Tables}

Table 1.

\begin{tabular}{|c|c|c|c|}
\hline \multicolumn{4}{|c|}{100 Highest-Cited Articles in Radiology 2009-2019 } \\
\hline Rank & 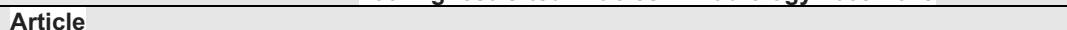 & Citations & $\mathrm{CNCl}$ \\
\hline 1 & $\begin{array}{l}\text { Rubinov, M. and Sporns, O., 2010. Complex network measures of brain connectivity: uses and } \\
\text { interpretations. Neuroimage, 52(3), pp.1059-1069. }\end{array}$ & 4008 & 119.6 \\
\hline 2 & $\begin{array}{l}\text { Jenkinson, M., Beckmann, C.F., Behrens, T.E., Woolrich, M.W. and Smith, S.M., } 2012 . \\
\text { Fsl. Neuroimage, 62(2), pp.782-790. }\end{array}$ & 3327 & 60.8 \\
\hline 3 & $\begin{array}{l}\text { Power, J.D., Barnes, K.A., Snyder, A.Z., Schlaggar, B.L. and Petersen, S.E., 2012. Spurious but } \\
\text { systematic correlations in functional connectivity MRI networks arise from subject } \\
\text { motion. Neuroimage, 59(3), pp.2142-2154. }\end{array}$ & 3142 & 116.6 \\
\hline 4 & $\begin{array}{l}\text { Lang, R.M., Badano, L.P., Mor-Avi, V., Afilalo, J., Armstrong, A., Ernande, L., Flachskampf, F.A., } \\
\text { Foster, E., Goldstein, S.A., Kuznetsova, T. and Lancellotti, P., 2015. Recommendations for } \\
\text { cardiac chamber quantification by echocardiography in adults: an update from the American } \\
\text { Society of Echocardiography and the European Association of Cardiovascular Imaging. European } \\
\text { Heart Journal-Cardiovascular Imaging, 16(3), pp.233-271. }\end{array}$ & 2769 & 198.8 \\
\hline 5 & $\begin{array}{l}\text { Smith, S.M. and Nichols, T.E., 2009. Threshold-free cluster enhancement: addressing problems } \\
\text { of smoothing, threshold dependence and localisation in cluster inference. Neuroimage, 44(1), } \\
\text { pp.83-98. }\end{array}$ & 2375 & 64.9 \\
\hline 6 & Fischl, B., 2012. FreeSurfer. Neuroimage, 62(2), pp.774-781. & 1797 & 32.8 \\
\hline 7 & $\begin{array}{l}\text { Klein, S., Staring, M., Murphy, K., Viergever, M.A. and Pluim, J.P., 2009. Elastix: a toolbox for } \\
\text { intensity-based medical image registration. IEEE transactions on medical imaging, 29(1), pp.196- } \\
205 .\end{array}$ & 1547 & 59.5 \\
\hline 8 & $\begin{array}{l}\text { Nagueh, S.F., Smiseth, O.A., Appleton, C.P., Byrd, B.F., Dokainish, H., Edvardsen, T., } \\
\text { Flachskampf, F.A., Gillebert, T.C., Klein, A.L., Lancellotti, P. and Marino, P., } 2016 . \\
\text { Recommendations for the evaluation of left ventricular diastolic function by echocardiography: an } \\
\text { update from the American Society of Echocardiography and the European Association of } \\
\text { Cardiovascular Imaging. European Journal of Echocardiography, 17(12), pp.1321-1360. }\end{array}$ & 1530 & 110.0 \\
\hline 9 & $\begin{array}{l}\text { Fedorov, A., Beichel, R., Kalpathy-Cramer, J., Finet, J., Fillion-Robin, J.C., Pujol, S., Bauer, C., } \\
\text { Jennings, D., Fennessy, F., Sonka, M. and Buatti, J., 2012. 3D Slicer as an image computing } \\
\text { platform for the Quantitative Imaging Network. Magnetic resonance imaging, 30(9), pp.1323- } \\
1341 .\end{array}$ & 1447 & 71.8 \\
\hline 10 & $\begin{array}{l}\text { Litjens, G., Kooi, T., Bejnordi, B.E., Setio, A.A.A., Ciompi, F., Ghafoorian, M., Van Der Laak, J.A., } \\
\text { Van Ginneken, B. and Sánchez, C.I., 2017. A survey on deep learning in medical image } \\
\text { analysis. Medical image analysis, 42, pp.60-88. }\end{array}$ & 1354 & 170.3 \\
\hline 11 & $\begin{array}{l}\text { Murphy, K., Birn, R.M., Handwerker, D.A., Jones, T.B. and Bandettini, P.A., 2009. The impact of } \\
\text { global signal regression on resting state correlations: are anti-correlated networks } \\
\text { introduced?. Neuroimage, } 44(3) \text {, pp.893-905. }\end{array}$ & 1353 & 37.0 \\
\hline 12 & $\begin{array}{l}\text { Van Dijk, K.R., Sabuncu, M.R. and Buckner, R.L., 2012. The influence of head motion on intrinsic } \\
\text { functional connectivity MRI. Neuroimage, 59(1), pp.431-438. }\end{array}$ & 1351 & 50.1 \\
\hline 13 & $\begin{array}{l}\text { Nagueh, S.F., Appleton, C.P., Gillebert, T.C., Marino, P.N., Oh, J.K., Smiseth, O.A., Waggoner, } \\
\text { A.D., Flachskampf, F.A., Pellikka, P.A. and Evangelisa, A., 2009. Recommendations for the } \\
\text { evaluation of left ventricular diastolic function by echocardiography. European Journal of } \\
\text { Echocardiography, 10(2), pp.165-193. }\end{array}$ & 1335 & 25.0 \\
\hline 14 & $\begin{array}{l}\text { Jacques, S.L., 2013. Optical properties of biological tissues: a review. Physics in Medicine \& } \\
\text { Biology, 58(11), p.R37. }\end{array}$ & 1317 & 37.2 \\
\hline 15 & $\begin{array}{l}\text { Barentsz, J.O., Richenberg, J., Clements, R., Choyke, P., Verma, S., Villeirs, G., Rouviere, O., } \\
\text { Logager, V. and Fütterer, J.J., 2012. ESUR prostate MR guidelines 2012. European } \\
\text { radiology, 22(4), pp.746-757. }\end{array}$ & 1282 & 63.7 \\
\hline 16 & $\begin{array}{l}\text { Klein, A., Andersson, J., Ardekani, B.A., Ashburner, J., Avants, B., Chiang, M.C., Christensen, } \\
\text { G.E., Collins, D.L., Gee, J., Hellier, P. and Song, J.H., 2009. Evaluation of } 14 \text { nonlinear } \\
\text { deformation algorithms applied to human brain MRI registration. Neuroimage, 46(3), pp.786-802. }\end{array}$ & 1188 & 32.5 \\
\hline 17 & $\begin{array}{l}\text { Van Essen, D.C., Smith, S.M., Barch, D.M., Behrens, T.E., Yacoub, E., Ugurbil, K. and Wu-Minn } \\
\text { HCP Consortium, 2013. The WU-Minn human connectome project: an } \\
\text { overview. Neuroimage, 80, pp.62-79. }\end{array}$ & 1168 & 51.3 \\
\hline
\end{tabular}


medRxiv preprint doi: https://doi.org/10.1101/2020.11.14.20231944; this version posted November 17, 2020. The copyright holder for this preprint (which was not certified by peer review) is the author/funder, who has granted medRxiv a license to display the preprint in It is made available under a CC-BY-NC-ND 4.0 International license .

\begin{tabular}{|c|c|c|c|}
\hline 18 & $\begin{array}{l}\text { Gillies, R.J., Kinahan, P.E. and Hricak, H., 2016. Radiomics: images are more than pictures, they } \\
\text { are data. Radiology, } 278(2) \text {, pp.563-577. }\end{array}$ & 1152 & 120.5 \\
\hline 19 & $\begin{array}{l}\text { Woolrich, M.W., Jbabdi, S., Patenaude, B., Chappell, M., Makni, S., Behrens, T., Beckmann, C., } \\
\text { Jenkinson, M. and Smith, S.M., 2009. Bayesian analysis of neuroimaging data in } \\
\text { FSL. Neuroimage, 45(1), pp.S173-S186. }\end{array}$ & 1142 & 31.2 \\
\hline 20 & $\begin{array}{l}\text { Tustison, N.J., Avants, B.B., Cook, P.A., Zheng, Y., Egan, A., Yushkevich, P.A. and Gee, J.C., } \\
\text { 2010. N4ITK: improved N3 bias correction. IEEE transactions on medical imaging, 29(6), } \\
\text { pp.1310-1320. }\end{array}$ & 1131 & 43.5 \\
\hline 21 & $\begin{array}{l}\text { Avants, B.B., Tustison, N.J., Song, G., Cook, P.A., Klein, A. and Gee, J.C., 2011. A reproducible } \\
\text { evaluation of ANTs similarity metric performance in brain image registration. Neuroimage, 54(3), } \\
\text { pp.2033-2044. }\end{array}$ & 1130 & 38.1 \\
\hline 22 & $\begin{array}{l}\text { Winkler, A.M., Ridgway, G.R., Webster, M.A., Smith, S.M. and Nichols, T.E., 2014. Permutation } \\
\text { inference for the general linear model. Neuroimage, 92, pp.381-397. }\end{array}$ & 1084 & 55.7 \\
\hline 23 & $\begin{array}{l}\text { Patenaude, B., Smith, S.M., Kennedy, D.N. and Jenkinson, M., 2011. A Bayesian model of shape } \\
\text { and appearance for subcortical brain segmentation. Neuroimage, 56(3), pp.907-922. }\end{array}$ & 1065 & 35.9 \\
\hline 24 & $\begin{array}{l}\text { Jones, D.K., Knösche, T.R. and Turner, R., 2013. White matter integrity, fiber count, and other } \\
\text { fallacies: the do's and don'ts of diffusion MRI. Neuroimage, 73, pp.239-254. }\end{array}$ & 1013 & 165.8 \\
\hline 25 & $\begin{array}{l}\text { Greve, D.N. and Fischl, B., 2009. Accurate and robust brain image alignment using boundary- } \\
\text { based registration. Neuroimage, 48(1), pp.63-72. }\end{array}$ & 1002 & 27.4 \\
\hline 26 & $\begin{array}{l}\text { Stoodley, C.J. and Schmahmann, J.D., 2009. Functional topography in the human cerebellum: a } \\
\text { meta-analysis of neuroimaging studies. Neuroimage, } 44(2), \text { pp.489-501. }\end{array}$ & 996 & 14.8 \\
\hline 27 & $\begin{array}{l}\text { Shin, H.C., Roth, H.R., Gao, M., Lu, L., Xu, Z., Nogues, I., Yao, J., Mollura, D. and Summers, } \\
\text { R.M., 2016. Deep convolutional neural networks for computer-aided detection: CNN } \\
\text { architectures, dataset characteristics and transfer learning. IEEE transactions on medical } \\
\text { imaging, 35(5), pp.1285-1298. }\end{array}$ & 991 & 93.0 \\
\hline 28 & $\begin{array}{l}\text { Glasser, M.F., Sotiropoulos, S.N., Wilson, J.A., Coalson, T.S., Fischl, B., Andersson, J.L., Xu, J., } \\
\text { Jbabdi, S., Webster, M., Polimeni, J.R. and Van Essen, D.C., 2013. The minimal preprocessing } \\
\text { pipelines for the Human Connectome Project. Neuroimage, 80, pp.105-124. }\end{array}$ & 987 & 43.4 \\
\hline 29 & $\begin{array}{l}\text { Eickhoff, S.B., Laird, A.R., Grefkes, C., Wang, L.E., Zilles, K. and Fox, P.T., 2009. Coordinate- } \\
\text { based activation likelihood estimation meta-analysis of neuroimaging data: A random-effects } \\
\text { approach based on empirical estimates of spatial uncertainty. Human brain mapping, 30(9), } \\
\text { pp.2907-2926. }\end{array}$ & 934 & 25.1 \\
\hline 30 & $\begin{array}{l}\text { Power, J.D., Mitra, A., Laumann, T.O., Snyder, A.Z., Schlaggar, B.L. and Petersen, S.E., } 2014 . \\
\text { Methods to detect, characterize, and remove motion artifact in resting state } \\
\text { fMRI. Neuroimage, } 84 \text {, pp.320-341. }\end{array}$ & 925 & 47.5 \\
\hline 31 & $\begin{array}{l}\text { Hutchison, R.M., Womelsdorf, T., Allen, E.A., Bandettini, P.A., Calhoun, V.D., Corbetta, M., Della } \\
\text { Penna, S., Duyn, J.H., Glover, G.H., Gonzalez-Castillo, J. and Handwerker, D.A., 2013. Dynamic } \\
\text { functional connectivity: promise, issues, and interpretations. Neuroimage, 80, pp.360-378. }\end{array}$ & 920 & 40.4 \\
\hline 32 & $\begin{array}{l}\text { Zalesky, A., Fornito, A. and Bullmore, E.T., 2010. Network-based statistic: identifying differences } \\
\text { in brain networks. Neuroimage, 53(4), pp.1197-1207. }\end{array}$ & 892 & 25.1 \\
\hline 33 & $\begin{array}{l}\text { Destrieux, C., Fischl, B., Dale, A. and Halgren, E., 2010. Automatic parcellation of human cortical } \\
\text { gyri and sulci using standard anatomical nomenclature. Neuroimage, 53(1), pp.1-15. }\end{array}$ & 884 & 25.0 \\
\hline 34 & $\begin{array}{l}\text { Price, C.J., 2012. A review and synthesis of the first } 20 \text { years of PET and fMRI studies of heard } \\
\text { speech, spoken language and reading. Neuroimage, } 62(2), \text { pp.816-847. }\end{array}$ & 884 & 15.8 \\
\hline 35 & $\begin{array}{l}\text { Pereira, F., Mitchell, T. and Botvinick, M., 2009. Machine learning classifiers and fMRI: a tutorial } \\
\text { overview. Neuroimage, 45(1), pp.S199-S209. }\end{array}$ & 878 & 23.5 \\
\hline 36 & $\begin{array}{l}\text { Smith, S.M., Miller, K.L., Salimi-Khorshidi, G., Webster, M., Beckmann, C.F., Nichols, T.E., } \\
\text { Ramsey, J.D. and Woolrich, M.W., 2011. Network modelling methods for } \\
\text { FMRI. Neuroimage, 54(2), pp.875-891. }\end{array}$ & 873 & 29.4 \\
\hline 37 & $\begin{array}{l}\text { Van Overwalle, F., 2009. Social cognition and the brain: a meta-analysis. Human brain } \\
\text { mapping, 30(3), pp.829-858. }\end{array}$ & 869 & 12.9 \\
\hline 38 & $\begin{array}{l}\text { Lamm, C., Decety, J. and Singer, T., 2011. Meta-analytic evidence for common and distinct } \\
\text { neural networks associated with directly experienced pain and empathy for } \\
\text { pain. Neuroimage, } 54(3), \text { pp.2492-2502. }\end{array}$ & 857 & 28.9 \\
\hline 39 & $\begin{array}{l}\text { Reuter, M., Schmansky, N.J., Rosas, H.D. and Fischl, B., 2012. Within-subject template } \\
\text { estimation for unbiased longitudinal image analysis. Neuroimage, 61(4), pp.1402-1418. }\end{array}$ & 851 & 31.6 \\
\hline 40 & $\begin{array}{l}\text { Zhang, H., Schneider, T., Wheeler-Kingshott, C.A. and Alexander, D.C., 2012. NODDI: practical } \\
\text { in vivo neurite orientation dispersion and density imaging of the human brain. Neuroimage, 61(4), } \\
\text { pp.1000-1016. }\end{array}$ & 831 & 30.8 \\
\hline 41 & $\begin{array}{l}\text { Christ, A., Kainz, W., Hahn, E.G., Honegger, K., Zefferer, M., Neufeld, E., Rascher, W., Janka, } \\
\text { R., Bautz, W., Chen, J. and Kiefer, B., 2009. The Virtual Family-development of surface-based } \\
\text { anatomical models of two adults and two children for dosimetric simulations. Physics in Medicine } \\
\text { \& Biology, 55(2), p.N23. }\end{array}$ & 767 & 28.0 \\
\hline 42 & $\begin{array}{l}\text { Leemans, A. and Jones, D.K., 2009. The B-matrix must be rotated when correcting for subject } \\
\text { motion in DTI data. Magnetic Resonance in Medicine: An Official Journal of the International } \\
\text { Society for Magnetic Resonance in Medicine, 61(6), pp.1336-1349. }\end{array}$ & 762 & 26.9 \\
\hline 43 & $\begin{array}{l}\text { Ferrari, M. and Quaresima, V., 2012. A brief review on the history of human functional near- } \\
\text { infrared spectroscopy (fNIRS) development and fields of application. Neuroimage, 63(2), pp.921- } \\
935 .\end{array}$ & 748 & 13.1 \\
\hline 44 & $\begin{array}{l}\text { Lammer, J., Malagari, K., Vogl, T., Pilleul, F., Denys, A., Watkinson, A., Pitton, M., Sergent, G., } \\
\text { Pfammatter, T., Terraz, S. and Benhamou, Y., 2010. Prospective randomized study of } \\
\text { doxorubicin-eluting-bead embolization in the treatment of hepatocellular carcinoma: results of the } \\
\text { PRECISION V study. Cardiovascular and interventional radiology, 33(1), pp.41-52. }\end{array}$ & 737 & 27.9 \\
\hline 45 & $\begin{array}{l}\text { Boellaard, R., O’Doherty, M.J., Weber, W.A., Mottaghy, F.M., Lonsdale, M.N., Stroobants, S.G., } \\
\text { Oyen, W.J., Kotzerke, J., Hoekstra, O.S., Pruim, J. and Marsden, P.K., 2010. FDG PET and } \\
\text { PET/CT: EANM procedure guidelines for tumour PET imaging: version 1.0. European journal of } \\
\text { nuclear medicine and molecular imaging, 37(1), p.181. }\end{array}$ & 730 & 29.2 \\
\hline 46 & $\begin{array}{l}\text { Stephan, K.E., Penny, W.D., Daunizeau, J., Moran, R.J. and Friston, K.J., 2009. Bayesian model } \\
\text { selection for group studies. Neuroimage, 46(4), pp.1004-1017. }\end{array}$ & 708 & 18.9 \\
\hline 47 & $\begin{array}{l}\text { Menze, B.H., Jakab, A., Bauer, S., Kalpathy-Cramer, J., Farahani, K., Kirby, J., Burren, Y., Porz, } \\
\text { N., Slotboom, J., Wiest, R. and Lanczi, L., 2014. The multimodal brain tumor image segmentation } \\
\text { benchmark (BRATS). IEEE transactions on medical imaging, 34(10), pp.1993-2024. }\end{array}$ & 706 & 50.6 \\
\hline
\end{tabular}


medRxiv preprint doi: https://doi.org/10.1101/2020.11.14.20231944; this version posted November 17, 2020. The copyright holder for this preprint (which was not certified by peer review) is the author/funder, who has granted medRxiv a license to display the preprint in It is made available under a CC-BY-NC-ND 4.0 International license .

\begin{tabular}{|c|c|c|c|}
\hline 48 & $\begin{array}{l}\text { Fonov, V., Evans, A.C., Botteron, K., Almli, C.R., McKinstry, R.C., Collins, D.L. and Brain } \\
\text { Development Cooperative Group, 2011. Unbiased average age-appropriate atlases for pediatric } \\
\text { studies. Neuroimage, 54(1), pp.313-327. }\end{array}$ & 704 & 23.1 \\
\hline 49 & $\begin{array}{l}\text { Yan, C.G., Cheung, B., Kelly, C., Colcombe, S., Craddock, R.C., Di Martino, A., Li, Q., Zuo, X.N., } \\
\text { Castellanos, F.X. and Milham, M.P., 2013. A comprehensive assessment of regional variation in } \\
\text { the impact of head micromovements on functional connectomics. Neuroimage, 76, pp.183-201. }\end{array}$ & 703 & 30.9 \\
\hline 50 & $\begin{array}{l}\text { Alsop, D.C., Detre, J.A., Golay, X., Günther, M., Hendrikse, J., Hernandez-Garcia, L., Lu, H., } \\
\text { Maclntosh, B.J., Parkes, L.M., Smits, M. and Van Osch, M.J., 2015. Recommended } \\
\text { implementation of arterial spin-labeled perfusion MRI for clinical applications: a consensus of the } \\
\text { ISMRM perfusion study group and the European consortium for ASL in dementia. Magnetic } \\
\text { resonance in medicine, 73(1), pp.102-116. }\end{array}$ & 698 & 33.7 \\
\hline 51 & $\begin{array}{l}\text { Lancellotti, P., Moura, L., Pierard, L.A., Agricola, E., Popescu, B.A., Tribouilloy, C., Hagendorff, } \\
\text { A., Monin, J.L., Badano, L., Zamorano, J.L. and European Association of Echocardiography, } \\
\text { 2010. European Association of Echocardiography recommendations for the assessment of } \\
\text { valvular regurgitation. Part 2: mitral and tricuspid regurgitation (native valve disease). European } \\
\text { Journal of Echocardiography, 11(4), pp.307-332. }\end{array}$ & 690 & 126.3 \\
\hline 52 & $\begin{array}{l}\text { Heimann, T. and Meinzer, H.P., 2009. Statistical shape models for 3D medical image } \\
\text { segmentation: a review. Medical image analysis, 13(4), pp.543-563. }\end{array}$ & 687 & 9.8 \\
\hline 53 & $\begin{array}{l}\text { Vercauteren, T., Pennec, X., Perchant, A. and Ayache, N., 2009. Diffeomorphic demons: Efficient } \\
\text { non-parametric image registration. Neurolmage, 45(1), pp.S61-S72. }\end{array}$ & 687 & 18.4 \\
\hline 54 & $\begin{array}{l}\text { Boellaard, R., Delgado-Bolton, R., Oyen, W.J., Giammarile, F., Tatsch, K., Eschner, W., } \\
\text { Verzijlbergen, F.J., Barrington, S.F., Pike, L.C., Weber, W.A. and Stroobants, S., 2015. FDG } \\
\text { PET/CT: EANM procedure guidelines for tumour imaging: version 2.0. European Journal of } \\
\text { nuclear medicine and molecular imaging, 42(2), pp.328-354. }\end{array}$ & 682 & 55.8 \\
\hline 55 & $\begin{array}{l}\text { Caspers, S., Zilles, K., Laird, A.R. and Eickhoff, S.B., 2010. ALE meta-analysis of action } \\
\text { observation and imitation in the human brain. Neuroimage, 50(3), pp.1148-1167. }\end{array}$ & 670 & 19.5 \\
\hline 56 & $\begin{array}{l}\text { Chang, C. and Glover, G.H., 2010. Time-frequency dynamics of resting-state brain connectivity } \\
\text { measured with fMRI. Neuroimage, 50(1), pp.81-98. }\end{array}$ & 667 & 19.4 \\
\hline 57 & $\begin{array}{l}\text { Van Essen, D.C., Ugurbil, K., Auerbach, E., Barch, D., Behrens, T.E.J., Bucholz, R., Chang, A., } \\
\text { Chen, L., Corbetta, M., Curtiss, S.W. and Della Penna, S., 2012. The Human Connectome } \\
\text { Project: a data acquisition perspective. Neuroimage, 62(4), pp.2222-2231. }\end{array}$ & 667 & 11.7 \\
\hline 58 & $\begin{array}{l}\text { Van Essen, D.C., Ugurbil, K., Auerbach, E., Barch, D., Behrens, T.E.J., Bucholz, R., Chang, A., } \\
\text { Chen, L., Corbetta, M., Curtiss, S.W. and Della Penna, S., 2012. The Human Connectome } \\
\text { Project: a data acquisition perspective. Neuroimage, 62(4), pp.2222-2231. }\end{array}$ & 664 & 26.0 \\
\hline 59 & $\begin{array}{l}\text { Van Overwalle, F. and Baetens, K., 2009. Understanding others' actions and goals by mirror and } \\
\text { mentalizing systems: a meta-analysis. Neuroimage, 48(3), pp.564-584. }\end{array}$ & 663 & 9.8 \\
\hline 60 & $\begin{array}{l}\text { Rengier, F., Mehndiratta, A., Von Tengg-Kobligk, H., Zechmann, C.M., Unterhinninghofen, R., } \\
\text { Kauczor, H.U. and Giesel, F.L., 2010. 3D printing based on imaging data: review of medical } \\
\text { applications. International journal of computer assisted radiology and surgery, 5(4), pp.335-341. }\end{array}$ & 663 & 14.7 \\
\hline 61 & $\begin{array}{l}\text { Hampshire, A., Chamberlain, S.R., Monti, M.M., Duncan, J. and Owen, A.M., 2010. The role of } \\
\text { the right inferior frontal gyrus: inhibition and attentional control. Neuroimage, 50(3), pp.1313- } \\
1319 .\end{array}$ & 656 & 19.1 \\
\hline 62 & $\begin{array}{l}\text { Satterthwaite, T.D., Elliott, M.A., Gerraty, R.T., Ruparel, K., Loughead, J., Calkins, M.E., Eickhoff, } \\
\text { S.B., Hakonarson, H., Gur, R.C., Gur, R.E. and Wolf, D.H., 2013. An improved framework for } \\
\text { confound regression and filtering for control of motion artifact in the preprocessing of resting-state } \\
\text { functional connectivity data. Neuroimage, } 64, \text { pp.240-256. }\end{array}$ & 645 & 28.4 \\
\hline 63 & $\begin{array}{l}\text { Treeby, B.E. and Cox, B.T., 2010. k-Wave: MATLAB toolbox for the simulation and reconstruction } \\
\text { of photoacoustic wave fields. Journal of biomedical optics, } 15(2), \text { p.021314. }\end{array}$ & 639 & 24.8 \\
\hline 64 & $\begin{array}{l}\text { Craddock, R.C., James, G.A., Holtzheimer III, P.E., Hu, X.P. and Mayberg, H.S., 2012. A whole } \\
\text { brain fMRI atlas generated via spatially constrained spectral clustering. Human brain } \\
\text { mapping, 33(8), pp.1914-1928. }\end{array}$ & 637 & 22.9 \\
\hline 65 & $\begin{array}{l}\text { Bartra, O., McGuire, J.T. and Kable, J.W., 2013. The valuation system: a coordinate-based meta- } \\
\text { analysis of BOLD fMRI experiments examining neural correlates of subjective } \\
\text { value. Neuroimage, } 76, \text { pp.412-427. }\end{array}$ & 637 & 28.0 \\
\hline 66 & $\begin{array}{l}\text { Zalesky, A., Fornito, A., Harding, I.H., Cocchi, L., Yücel, M., Pantelis, C. and Bullmore, E.T., } \\
\text { 2010. Whole-brain anatomical networks: does the choice of nodes matter?. Neuroimage, 50(3), } \\
\text { pp.970-983. }\end{array}$ & 631 & 18.4 \\
\hline 67 & $\begin{array}{l}\text { Marks, L.B., Yorke, E.D., Jackson, A., Ten Haken, R.K., Constine, L.S., Eisbruch, A., Bentzen, } \\
\text { S.M., Nam, J. and Deasy, J.O., 2010. Use of normal tissue complication probability models in the } \\
\text { clinic. International Journal of Radiation Oncology* Biology* Physics, 76(3), pp.S10-S19. }\end{array}$ & 619 & 20.4 \\
\hline 68 & $\begin{array}{l}\text { McDonald, R.J., McDonald, J.S., Kallmes, D.F., Jentoft, M.E., Murray, D.L., Thielen, K.R., } \\
\text { Williamson, E.E. and Eckel, L.J., 2015. Intracranial gadolinium deposition after contrast- } \\
\text { enhanced MR imaging. Radiology, 275(3), pp.772-782. }\end{array}$ & 619 & 50.7 \\
\hline 69 & $\begin{array}{l}\text { McLaren, D.G., Ries, M.L., Xu, G. and Johnson, S.C., 2012. A generalized form of context- } \\
\text { dependent psychophysiological interactions (gPPI): a comparison to standard } \\
\text { approaches. Neuroimage, } 61(4) \text {, pp.1277-1286. }\end{array}$ & 612 & 22.0 \\
\hline 70 & $\begin{array}{l}\text { Zuo, X.N., Di Martino, A., Kelly, C., Shehzad, Z.E., Gee, D.G., Klein, D.F., Castellanos, F.X., } \\
\text { Biswal, B.B. and Milham, M.P., 2010. The oscillating brain: complex and } \\
\text { reliable. Neuroimage, } 49(2), \text { pp.1432-1445. }\end{array}$ & 604 & 19.9 \\
\hline 71 & $\begin{array}{l}\text { Setsompop, K., Gagoski, B.A., Polimeni, J.R., Witzel, T., Wedeen, V.J. and Wald, L.L., } 2012 . \\
\text { Blipped-controlled aliasing in parallel imaging for simultaneous multislice echo planar imaging } \\
\text { with reduced g-factor penalty. Magnetic resonance in medicine, } 67(5) \text {, pp.1210-1224. }\end{array}$ & 600 & 28.9 \\
\hline 72 & $\begin{array}{l}\text { Zhang, D., Wang, Y., Zhou, L., Yuan, H., Shen, D. and Alzheimer's Disease Neuroimaging } \\
\text { Initiative, 2011. Multimodal classification of Alzheimer's disease and mild cognitive } \\
\text { impairment. Neuroimage, 55(3), pp.856-867. }\end{array}$ & 597 & 19.6 \\
\hline 73 & $\begin{array}{l}\text { Wheeler-Kingshott, C.A. and Cercignani, M., 2009. About "axial" and "radial" } \\
\text { diffusivities. Magnetic Resonance in Medicine: An Official Journal of the International Society for } \\
\text { Magnetic Resonance in Medicine, 61(5), pp.1255-1260. }\end{array}$ & 595 & 19.8 \\
\hline 74 & $\begin{array}{l}\text { Uddin, L.Q., Clare Kelly, A.M., Biswal, B.B., Xavier Castellanos, F. and Milham, M.P., } 2009 . \\
\text { Functional connectivity of default mode network components: correlation, anticorrelation, and } \\
\text { causality. Human brain mapping, 30(2), pp.625-637. }\end{array}$ & 592 & 15.8 \\
\hline 75 & $\begin{array}{l}\text { Van Den Heuvel, M.P., Mandl, R.C., Kahn, R.S. and Hulshoff Pol, H.E., 2009. Functionally linked } \\
\text { resting-state networks reflect the underlying structural connectivity architecture of the human } \\
\text { brain. Human brain mapping, } 30(10) \text {, pp.3127-3141. }\end{array}$ & 587 & 15.7 \\
\hline
\end{tabular}


medRxiv preprint doi: https://doi.org/10.1101/2020.11.14.20231944; this version posted November 17, 2020. The copyright holder for this preprint (which was not certified by peer review) is the author/funder, who has granted medRxiv a license to display the preprint in It is made available under a CC-BY-NC-ND 4.0 International license .

\begin{tabular}{|c|c|c|c|}
\hline 76 & $\begin{array}{l}\text { Lu, G. and Fei, B., 2014. Medical hyperspectral imaging: a review. Journal of biomedical } \\
\text { optics, 19(1), p.010901. }\end{array}$ & 586 & 15.8 \\
\hline 77 & $\begin{array}{l}\text { Eickhoff, S.B., Bzdok, D., Laird, A.R., Kurth, F. and Fox, P.T., 2012. Activation likelihood } \\
\text { estimation meta-analysis revisited. Neuroimage, 59(3), pp.2349-2361. }\end{array}$ & 584 & 21.0 \\
\hline 78 & $\begin{array}{l}\text { International Commission on Non-lonizing Radiation Protection, } 2010 \text {. Guidelines for limiting } \\
\text { exposure to time-varying electric and magnetic fields (1 Hz to } 100 \mathrm{kHz}) \text {. Health physics, 99(6), } \\
\text { pp.818-836. }\end{array}$ & 582 & 30.2 \\
\hline 79 & $\begin{array}{l}\text { Kamnitsas, K., Ledig, C., Newcombe, V.F., Simpson, J.P., Kane, A.D., Menon, D.K., Rueckert, D. } \\
\text { and Glocker, B., 2017. Efficient multi-scale 3D CNN with fully connected CRF for accurate brain } \\
\text { lesion segmentation. Medical image analysis, 36, pp.61-78. }\end{array}$ & 579 & 72.8 \\
\hline 80 & $\begin{array}{l}\text { Satterthwaite, T.D., Wolf, D.H., Loughead, J., Ruparel, K., Elliott, M.A., Hakonarson, H., Gur, } \\
\text { R.C. and Gur, R.E., 2012. Impact of in-scanner head motion on multiple measures of functional } \\
\text { connectivity: relevance for studies of neurodevelopment in youth. Neuroimage, 60(1), pp.623- } \\
632 .\end{array}$ & 578 & 20.8 \\
\hline 81 & $\begin{array}{l}\text { Jensen, J.H. and Helpern, J.A., 2010. MRI quantification of non-Gaussian water diffusion by } \\
\text { kurtosis analysis. NMR in Biomedicine, 23(7), pp.698-710. }\end{array}$ & 577 & 11.1 \\
\hline 82 & $\begin{array}{l}\text { Armato III, S.G., McLennan, G., Bidaut, L., McNitt-Gray, M.F., Meyer, C.R., Reeves, A.P., Zhao, } \\
\text { B., Aberle, D.R., Henschke, C.I., Hoffman, E.A. and Kazerooni, E.A., 2011. The lung image } \\
\text { database consortium (LIDC) and image database resource initiative (IDRI): a completed } \\
\text { reference database of lung nodules on CT scans. Medical physics, 38(2), pp.915-931. }\end{array}$ & 570 & 22.2 \\
\hline 83 & $\begin{array}{l}\text { Havaei, M., Davy, A., Warde-Farley, D., Biard, A., Courville, A., Bengio, Y., Pal, C., Jodoin, P.M. } \\
\text { and Larochelle, H., 2017. Brain tumor segmentation with deep neural networks. Medical image } \\
\text { analysis, 35, pp.18-31. }\end{array}$ & 570 & 71.7 \\
\hline 84 & $\begin{array}{l}\text { Winkler, A.M., Kochunov, P., Blangero, J., Almasy, L., Zilles, K., Fox, P.T., Duggirala, R. and } \\
\text { Glahn, D.C., 2010. Cortical thickness or grey matter volume? The importance of selecting the } \\
\text { phenotype for imaging genetics studies. Neuroimage, 53(3), pp.1135-1146. }\end{array}$ & 560 & 16.3 \\
\hline 85 & $\begin{array}{l}\text { Spreng, R.N., Stevens, W.D., Chamberlain, J.P., Gilmore, A.W. and Schacter, D.L., 2010. Default } \\
\text { network activity, coupled with the frontoparietal control network, supports goal-directed } \\
\text { cognition. Neuroimage, 53(1), pp.303-317. }\end{array}$ & 558 & 16.2 \\
\hline 86 & $\begin{array}{l}\text { Kumar, V., Gu, Y., Basu, S., Berglund, A., Eschrich, S.A., Schabath, M.B., Forster, K., Aerts, } \\
\text { H.J., Dekker, A., Fenstermacher, D. and Goldgof, D.B., 2012. Radiomics: the process and the } \\
\text { challenges. Magnetic resonance imaging, 30(9), pp.1234-1248. }\end{array}$ & 557 & 27.7 \\
\hline 87 & $\begin{array}{l}\text { Tajbakhsh, N., Shin, J.Y., Gurudu, S.R., Hurst, R.T., Kendall, C.B., Gotway, M.B. and Liang, J., } \\
\text { 2016. Convolutional neural networks for medical image analysis: Full training or fine } \\
\text { tuning?. IEEE transactions on medical imaging, 35(5), pp.1299-1312. }\end{array}$ & 557 & 52.3 \\
\hline 88 & $\begin{array}{l}\text { Calhoun, V.D., Liu, J. and Adalı, T., 2009. A review of group ICA for fMRI data and ICA for joint } \\
\text { inference of imaging, genetic, and ERP data. Neuroimage, 45(1), pp.S163-S172. }\end{array}$ & 554 & 14.8 \\
\hline 89 & $\begin{array}{l}\text { Blankertz, B., Lemm, S., Treder, M., Haufe, S. and Müller, K.R., 2011. Single-trial analysis and } \\
\text { classification of ERP components-a tutorial. Neurolmage, 56(2), pp.814-825. }\end{array}$ & 552 & 18.1 \\
\hline 90 & $\begin{array}{l}\text { Sotiras, A., Davatzikos, C. and Paragios, N., 2013. Deformable medical image registration: A } \\
\text { survey. IEEE transactions on medical imaging, 32(7), pp.1153-1190. }\end{array}$ & 552 & 29.9 \\
\hline 91 & $\begin{array}{l}\text { Haacke, E.M., Mittal, S., Wu, Z., Neelavalli, J. and Cheng, Y.C., 2009. Susceptibility-weighted } \\
\text { imaging: technical aspects and clinical applications, part 1. American Journal of } \\
\text { Neuroradiology, 30(1), pp.19-30. }\end{array}$ & 548 & 9.3 \\
\hline 92 & $\begin{array}{l}\text { Aljabar, P., Heckemann, R.A., Hammers, A., Hajnal, J.V. and Rueckert, D., 2009. Multi-atlas } \\
\text { based segmentation of brain images: atlas selection and its effect on } \\
\text { accuracy. Neuroimage, } 46(3), \text { pp.726-738. }\end{array}$ & 547 & 14.6 \\
\hline 93 & $\begin{array}{l}\text { Kanda, T., Ishii, K., Kawaguchi, H., Kitajima, K. and Takenaka, D., 2014. High signal intensity in } \\
\text { the dentate nucleus and globus pallidus on unenhanced T1-weighted MR images: relationship } \\
\text { with increasing cumulative dose of a gadolinium-based contrast material. Radiology, 270(3), } \\
\text { pp.834-841. }\end{array}$ & 541 & 36.3 \\
\hline 94 & $\begin{array}{l}\text { Eiber, 2016. " Evaluation of Hybrid Ga-68-PSMA Ligand PET/CT in } 248 \text { Patients with } \\
\text { Biochemical Recurrence After Radical Prostatectomy"(vol 56, pg 668, 2015). Journal of nuclear } \\
\text { medicine, 57(8), pp.1325-1325. }\end{array}$ & 538 & 44.0 \\
\hline 95 & $\begin{array}{l}\text { Andersson, J.L. and Sotiropoulos, S.N., 2016. An integrated approach to correction for off- } \\
\text { resonance effects and subject movement in diffusion MR imaging. Neuroimage, 125, pp.1063- } \\
1078 .\end{array}$ & 538 & 45.6 \\
\hline 96 & $\begin{array}{l}\text { Sodickson, A., Baeyens, P.F., Andriole, K.P., Prevedello, L.M., Nawfel, R.D., Hanson, R. and } \\
\text { Khorasani, R., 2009. Recurrent CT, cumulative radiation exposure, and associated radiation- } \\
\text { induced cancer risks from CT of adults. Radiology, 251(1), pp.175-184. }\end{array}$ & 534 & 18.9 \\
\hline 97 & $\begin{array}{l}\text { Clark, K., Vendt, B., Smith, K., Freymann, J., Kirby, J., Koppel, P., Moore, S., Phillips, S., Maffitt, } \\
\text { D., Pringle, M. and Tarbox, L., 2013. The Cancer Imaging Archive (TCIA): maintaining and } \\
\text { operating a public information repository. Journal of digital imaging, 26(6), pp.1045-1057. }\end{array}$ & 527 & 29.7 \\
\hline 98 & $\begin{array}{l}\text { Bamber, J., Cosgrove, D., Dietrich, C.F., Fromageau, J., Bojunga, J., Calliada, F., Cantisani, V., } \\
\text { Correas, J.M., D'onofrio, M., Drakonaki, E.E. and Fink, M., 2013. EFSUMB guidelines and } \\
\text { recommendations on the clinical use of ultrasound elastography. Part 1: Basic principles and } \\
\text { technology. Ultraschall in der Medizin-European Journal of Ultrasound, 34(02), pp.169-184. }\end{array}$ & 523 & 33.6 \\
\hline 99 & $\begin{array}{l}\text { Piscaglia, F., Nolsøe, C., Dietrich, C.A., Cosgrove, D.O., Gilja, O.H., Nielsen, M.B., Albrecht, T., } \\
\text { Barozzi, L., Bertolotto, M., Catalano, O. and Claudon, M., 2012. The EFSUMB Guidelines and } \\
\text { Recommendations on the Clinical Practice of Contrast Enhanced Ultrasound (CEUS): update } \\
2011 \text { on non-hepatic applications. Ultraschall in der Medizin-European Journal of } \\
\text { Ultrasound, 33(01), pp.33-59. }\end{array}$ & 506 & 29.3 \\
\hline 100 & $\begin{array}{l}\text { Afshar-Oromieh, A., Zechmann, C.M., Malcher, A., Eder, M., Eisenhut, M., Linhart, H.G., Holland- } \\
\text { Letz, T., Hadaschik, B.A., Giesel, F.L., Debus, J. and Haberkorn, U., 2014. Comparison of PET } \\
\text { imaging with a } 68 \text { Ga-labelled PSMA ligand and } 18 \text { F-choline-based PET/CT for the diagnosis of } \\
\text { recurrent prostate cancer. European journal of nuclear medicine and molecular imaging, 41(1), } \\
\text { pp.11-20. }\end{array}$ & 506 & 33.9 \\
\hline
\end{tabular}


medRxiv preprint doi: https://doi.org/10.1101/2020.11.14.20231944; this version posted November 17, 2020. The copyright holder for this preprint (which was not certified by peer review) is the author/funder, who has granted medRxiv a license to display the preprint in

It is made available under a CC-BY-NC-ND 4.0 International license .

Table 2.

\begin{tabular}{|c|c|c|c|}
\hline \multicolumn{4}{|c|}{100 Highest-CNCI Articles in Radiology (2009-2019) } \\
\hline Rank & Article & Citations & $\mathrm{CNCl}$ \\
\hline 1 & $\begin{array}{l}\text { Lang, R.M., Badano, L.P., Mor-Avi, V., Afilalo, J., Armstrong, A., Ernande, L., Flachskampf, F.A., } \\
\text { Foster, E., Goldstein, S.A., Kuznetsova, T. and Lancellotti, P., 2015. Recommendations for } \\
\text { cardiac chamber quantification by echocardiography in adults: an update from the American } \\
\text { Society of Echocardiography and the European Association of Cardiovascular Imaging. European } \\
\text { Heart Journal-Cardiovascular Imaging, 16(3), pp.233-271. }\end{array}$ & 2769 & 198.8 \\
\hline 2 & $\begin{array}{l}\text { Litjens, G., Kooi, T., Bejnordi, B.E., Setio, A.A.A., Ciompi, F., Ghafoorian, M., Van Der Laak, J.A., } \\
\text { Van Ginneken, B. and Sánchez, C.I., 2017. A survey on deep learning in medical image } \\
\text { analysis. Medical image analysis, 42, pp.60-88. }\end{array}$ & 1354 & 170.3 \\
\hline 3 & $\begin{array}{l}\text { Jones, D.K., Knösche, T.R. and Turner, R., 2013. White matter integrity, fiber count, and other } \\
\text { fallacies: the do's and don'ts of diffusion MRI. Neuroimage, 73, pp.239-254. }\end{array}$ & 1013 & 165.8 \\
\hline 4 & $\begin{array}{l}\text { Greenspan, H., Van Ginneken, B. and Summers, R.M., 2016. Guest editorial deep learning in } \\
\text { medical imaging: Overview and future promise of an exciting new technique. IEEE Transactions } \\
\text { on Medical Imaging, 35(5), pp.1153-1159. }\end{array}$ & 424 & 139.9 \\
\hline 5 & $\begin{array}{l}\text { Oliveira Melo, A.S., Malinger, G., Ximenes, R., Szejnfeld, P.O., Alves Sampaio, S. and Bispo de } \\
\text { Filippis, A.M., 2016. Zika virus intrauterine infection causes fetal brain abnormality and } \\
\text { microcephaly: tip of the iceberg?. Ultrasound in Obstetrics \& Gynecology, 47(1), pp.6-7. }\end{array}$ & 409 & 136.7 \\
\hline 6 & $\begin{array}{l}\text { Gillies, R.J., Kinahan, P.E. and Hricak, H., 2016. Radiomics: images are more than pictures, they } \\
\text { are data. Radiology, } 278(2) \text {, pp.563-577. }\end{array}$ & 1152 & 120.5 \\
\hline 7 & $\begin{array}{l}\text { Rubinov, M. and Sporns, O., 2010. Complex network measures of brain connectivity: uses and } \\
\text { interpretations. Neuroimage, 52(3), pp.1059-1069. }\end{array}$ & 4008 & 119.6 \\
\hline 8 & $\begin{array}{l}\text { Power, J.D., Barnes, K.A., Snyder, A.Z., Schlaggar, B.L. and Petersen, S.E., 2012. Spurious but } \\
\text { systematic correlations in functional connectivity MRI networks arise from subject } \\
\text { motion. Neuroimage, } 59(3) \text {, pp.2142-2154. }\end{array}$ & 3142 & 116.6 \\
\hline 9 & $\begin{array}{l}\text { Shin, H.C., Roth, H.R., Gao, M., Lu, L., Xu, Z., Nogues, I., Yao, J., Mollura, D. and Summers, } \\
\text { R.M., 2016. Deep convolutional neural networks for computer-aided detection: CNN } \\
\text { architectures, dataset characteristics and transfer learning. IEEE transactions on medical } \\
\text { imaging, 35(5), pp.1285-1298. }\end{array}$ & 991 & 93.0 \\
\hline 10 & $\begin{array}{l}\text { Kamnitsas, K., Ledig, C., Newcombe, V.F., Simpson, J.P., Kane, A.D., Menon, D.K., Rueckert, D. } \\
\text { and Glocker, B., 2017. Efficient multi-scale 3D CNN with fully connected CRF for accurate brain } \\
\text { lesion segmentation. Medical image analysis, 36, pp.61-78. }\end{array}$ & 579 & 72.8 \\
\hline 11 & $\begin{array}{l}\text { Fedorov, A., Beichel, R., Kalpathy-Cramer, J., Finet, J., Fillion-Robin, J.C., Pujol, S., Bauer, C., } \\
\text { Jennings, D., Fennessy, F., Sonka, M. and Buatti, J., 2012. 3D Slicer as an image computing } \\
\text { platform for the Quantitative Imaging Network. Magnetic resonance imaging, 30(9), pp.1323- } \\
1341 .\end{array}$ & 1447 & 71.8 \\
\hline 12 & $\begin{array}{l}\text { Havaei, M., Davy, A., Warde-Farley, D., Biard, A., Courville, A., Bengio, Y., Pal, C., Jodoin, P.M. } \\
\text { and Larochelle, H., 2017. Brain tumor segmentation with deep neural networks. Medical image } \\
\text { analysis, 35, pp.18-31. }\end{array}$ & 570 & 71.7 \\
\hline 13 & $\begin{array}{l}\text { Smith, S.M. and Nichols, T.E., 2009. Threshold-free cluster enhancement: addressing problems } \\
\text { of smoothing, threshold dependence and localisation in cluster inference. Neuroimage, 44(1), } \\
\text { pp.83-98. }\end{array}$ & 2375 & 64.9 \\
\hline 14 & $\begin{array}{l}\text { Barentsz, J.O., Richenberg, J., Clements, R., Choyke, P., Verma, S., Villeirs, G., Rouviere, O., } \\
\text { Logager, V. and Fütterer, J.J., 2012. ESUR prostate MR guidelines 2012. European } \\
\text { radiology, 22(4), pp.746-757. }\end{array}$ & 1282 & 63.7 \\
\hline 15 & $\begin{array}{l}\text { Chen, J., Lemyre, L., Wilkins, R. and Wilkinson, D., 2010. Radiation Protection Dosimetry. } \\
\text { Preface. Radiation protection dosimetry, 142(1), pp.1-1. }\end{array}$ & 311 & 62.9 \\
\hline 16 & $\begin{array}{l}\text { Wahl, R.L., Jacene, H., Kasamon, Y. and Lodge, M.A., 2009. From RECIST to PERCIST: } \\
\text { evolving considerations for PET response criteria in solid tumors. Journal of nuclear medicine: } \\
\text { official publication, Society of Nuclear Medicine, } 50 \text { (Suppl 1), p.122S. }\end{array}$ & 1708 & 61.6 \\
\hline 17 & $\begin{array}{l}\text { Jenkinson, M., Beckmann, C.F., Behrens, T.E., Woolrich, M.W. and Smith, S.M., } 2012 . \\
\text { Fsl. Neuroimage, 62(2), pp.782-790. }\end{array}$ & 3327 & 60.8 \\
\hline 18 & $\begin{array}{l}\text { Klein, S., Staring, M., Murphy, K., Viergever, M.A. and Pluim, J.P., 2009. Elastix: a toolbox for } \\
\text { intensity-based medical image registration. IEEE transactions on medical imaging, 29(1), pp.196- } \\
205 .\end{array}$ & 1547 & 59.5 \\
\hline 19 & $\begin{array}{l}\text { Lemm, S., Blankertz, B., Dickhaus, T. and Müller, K.R., 2011. Introduction to machine learning for } \\
\text { brain imaging. Neuroimage, 56(2), p.387-399. }\end{array}$ & 322 & 58.2 \\
\hline 20 & $\begin{array}{l}\text { Potter, E. and Marwick, T.H., 2018. Assessment of left ventricular function by echocardiography: } \\
\text { the case for routinely adding global longitudinal strain to ejection fraction. JACC: Cardiovascular } \\
\text { Imaging, } 11(2 \text { Part 1), pp.260-274. }\end{array}$ & 57 & 56.0 \\
\hline 21 & $\begin{array}{l}\text { Boellaard, R., Delgado-Bolton, R., Oyen, W.J., Giammarile, F., Tatsch, K., Eschner, W., } \\
\text { Verzijlbergen, F.J., Barrington, S.F., Pike, L.C., Weber, W.A. and Stroobants, S., 2015. FDG } \\
\text { PET/CT: EANM procedure guidelines for tumour imaging: version 2.0. European journal of } \\
\text { nuclear medicine and molecular imaging, 42(2), pp.328-354. }\end{array}$ & 682 & 55.8 \\
\hline 22 & $\begin{array}{l}\text { Winkler, A.M., Ridgway, G.R., Webster, M.A., Smith, S.M. and Nichols, T.E., 2014. Permutation } \\
\text { inference for the general linear model. Neuroimage, 92, pp.381-397. }\end{array}$ & 1084 & 55.7 \\
\hline 23 & $\begin{array}{l}\text { McCollough, C.H., Leng, S., Yu, L., Cody, D.D., Boone, J.M. and McNitt-Gray, M.F., 2011. CT } \\
\text { dose index and patient dose: they are not the same thing. Radiology, 259(2), pp.311-316. }\end{array}$ & 216 & 54.6 \\
\hline 24 & $\begin{array}{l}\text { MacMahon, H., Naidich, D.P., Goo, J.M., Lee, K.S., Leung, A.N., Mayo, J.R., Mehta, A.C., Ohno, } \\
\text { Y., Powell, C.A., Prokop, M. and Rubin, G.D., 2017. Guidelines for management of incidental } \\
\text { pulmonary nodules detected on CT images: from the Fleischner Society 2017. Radiology, 284(1), } \\
\text { pp.228-243. }\end{array}$ & 397 & 54.1 \\
\hline 25 & $\begin{array}{l}\text { Wald, C., Russo, M.W., Heimbach, J.K., Hussain, H.K., Pomfret, E.A. and Bruix, J., 2013. New } \\
\text { OPTN/UNOS policy for liver transplant allocation: standardization of liver imaging, diagnosis, } \\
\text { classification, and reporting of hepatocellular carcinoma. }\end{array}$ & 190 & 53.8 \\
\hline 26 & $\begin{array}{l}\text { Tajbakhsh, N., Shin, J.Y., Gurudu, S.R., Hurst, R.T., Kendall, C.B., Gotway, M.B. and Liang, J., } \\
\text { 2016. Convolutional neural networks for medical image analysis: Full training or fine } \\
\text { tuning?. IEEE transactions on medical imaging, 35(5), pp.1299-1312. }\end{array}$ & 557 & 52.3 \\
\hline 27 & $\begin{array}{l}\text { Schauer, D.A. and Linton, O.W., 2009. NCRP report No. 160, ionizing radiation exposure of the } \\
\text { population of the United States, medical exposure-are we doing less with more, and is there a } \\
\text { role for health physicists?. Health physics, } 97(1), \text { pp.1-5. }\end{array}$ & 139 & 52.0 \\
\hline
\end{tabular}


medRxiv preprint doi: https://doi.org/10.1101/2020.11.14.20231944; this version posted November 17, 2020. The copyright holder for this preprint (which was not certified by peer review) is the author/funder, who has granted medRxiv a license to display the preprint in It is made available under a CC-BY-NC-ND 4.0 International license .

\begin{tabular}{|c|c|c|c|}
\hline 28 & $\begin{array}{l}\text { Van Essen, D.C., Smith, S.M., Barch, D.M., Behrens, T.E., Yacoub, E., Ugurbil, K. and Wu-Minn } \\
\text { HCP Consortium, 2013. The WU-Minn human connectome project: an } \\
\text { overview. Neuroimage, 80, pp.62-79. }\end{array}$ & 1168 & 51.3 \\
\hline 29 & $\begin{array}{l}\text { McDonald, R.J., McDonald, J.S., Kallmes, D.F., Jentoft, M.E., Murray, D.L., Thielen, K.R., } \\
\text { Williamson, E.E. and Eckel, L.J., 2015. Intracranial gadolinium deposition after contrast- } \\
\text { enhanced MR imaging. Radiology, 275(3), pp.772-782. }\end{array}$ & 619 & 50.7 \\
\hline 30 & $\begin{array}{l}\text { Menze, B.H., Jakab, A., Bauer, S., Kalpathy-Cramer, J., Farahani, K., Kirby, J., Burren, Y., Porz, } \\
\text { N., Slotboom, J., Wiest, R. and Lanczi, L., 2014. The multimodal brain tumor image segmentation } \\
\text { benchmark (BRATS). IEEE transactions on medical imaging, 34(10), pp.1993-2024. }\end{array}$ & 706 & 50.6 \\
\hline 31 & $\begin{array}{l}\text { Van Dijk, K.R., Sabuncu, M.R. and Buckner, R.L., 2012. The influence of head motion on intrinsic } \\
\text { functional connectivity MRI. Neuroimage, 59(1), pp.431-438. }\end{array}$ & 1351 & 50.1 \\
\hline 32 & $\begin{array}{l}\text { Wang, G., Ye, J.C., Mueller, K. and Fessler, J.A., 2018. Image reconstruction is a new frontier of } \\
\text { machine learning. IEEEE transactions on medical imaging, 37(6), pp.1289-1296. }\end{array}$ & 42 & 49.4 \\
\hline 33 & $\begin{array}{l}\text { Reeder, S.B., Hu, H.H. and Sirlin, C.B., 2012. Proton density fat-fraction: a standardized MR- } \\
\text { based biomarker of tissue fat concentration. Journal of magnetic resonance imaging: } \\
\text { JMRI, 36(5), p.1011. }\end{array}$ & 184 & 49.3 \\
\hline 34 & $\begin{array}{l}\text { Kanal, E. and Tweedle, M.F., 2015. Residual or retained gadolinium: practical implications for } \\
\text { radiologists and our patients. Radiology, } 275(3), \text { pp.630-634. }\end{array}$ & 124 & 48.0 \\
\hline 35 & $\begin{array}{l}\text { Power, J.D., Mitra, A., Laumann, T.O., Snyder, A.Z., Schlaggar, B.L. and Petersen, S.E., } 2014 . \\
\text { Methods to detect, characterize, and remove motion artifact in resting state } \\
\text { fMRI. Neuroimage, } 84, \text { pp.320-341. }\end{array}$ & 925 & 47.5 \\
\hline 36 & $\begin{array}{l}\text { Andersson, J.L. and Sotiropoulos, S.N., 2016. An integrated approach to correction for off- } \\
\text { resonance effects and subject movement in diffusion MR imaging. Neuroimage, 125, pp.1063- } \\
1078 \text {. }\end{array}$ & 538 & 45.6 \\
\hline 37 & $\begin{array}{l}\text { Silva, A.C., Morse, B.G., Hara, A.K., Paden, R.G., Hongo, N. and Pavlicek, W., 2011. Dual- } \\
\text { energy (spectral) CT: applications in abdominal imaging. Radiographics, 31(4), pp.1031-1046. }\end{array}$ & 180 & 45.5 \\
\hline 38 & $\begin{array}{l}\text { Vallières, M., Zwanenburg, A., Badic, B., Le Rest, C.C., Visvikis, D. and Hatt, M., } 2018 . \\
\text { Responsible radiomics research for faster clinical translation. }\end{array}$ & 45 & 44.2 \\
\hline 39 & $\begin{array}{l}\text { Eiber, 2016. " Evaluation of Hybrid Ga-68-PSMA Ligand PET/CT in } 248 \text { Patients with } \\
\text { Biochemical Recurrence After Radical Prostatectomy"(vol 56, pg 668, 2015). Journal of nuclear } \\
\text { medicine, } 57(8) \text {, pp.1325-1325. }\end{array}$ & 538 & 44.0 \\
\hline 40 & $\begin{array}{l}\text { Tustison, N.J., Avants, B.B., Cook, P.A., Zheng, Y., Egan, A., Yushkevich, P.A. and Gee, J.C., } \\
\text { 2010. N4ITK: improved N3 bias correction. IEEE transactions on medical imaging, 29(6), } \\
\text { pp.1310-1320. }\end{array}$ & 1131 & 43.5 \\
\hline 41 & $\begin{array}{l}\text { Glasser, M.F., Sotiropoulos, S.N., Wilson, J.A., Coalson, T.S., Fischl, B., Andersson, J.L., Xu, J., } \\
\text { Jbabdi, S., Webster, M., Polimeni, J.R. and Van Essen, D.C., 2013. The minimal preprocessing } \\
\text { pipelines for the Human Connectome Project. Neuroimage, 80, pp.105-124. }\end{array}$ & 987 & 43.4 \\
\hline 42 & $\begin{array}{l}\text { Johnson, N.P., Kirkeeide, R.L. and Gould, K.L., 2012. Is discordance of coronary flow reserve } \\
\text { and fractional flow reserve due to methodology or clinically relevant coronary } \\
\text { pathophysiology?. JACC: Cardiovascular Imaging, 5(2), pp.193-202. }\end{array}$ & 162 & 43.1 \\
\hline 43 & $\begin{array}{l}\text { Pereira, S., Pinto, A., Alves, V. and Silva, C.A., 2016. Brain tumor segmentation using } \\
\text { convolutional neural networks in MRI images. IEEE transactions on medical imaging, 35(5), } \\
\text { pp.1240-1251. }\end{array}$ & 458 & 43.0 \\
\hline 44 & $\begin{array}{l}\text { Afshar-Oromieh, A., Avtzi, E., Giesel, F.L., Holland-Letz, T., Linhart, H.G., Eder, M., Eisenhut, M., } \\
\text { Boxler, S., Hadaschik, B.A., Kratochwil, C. and Weichert, W., 2015. The diagnostic value of } \\
\text { PET/CT imaging with the } 68 \text { Ga-labelled PSMA ligand HBED-CC in the diagnosis of recurrent } \\
\text { prostate cancer. European journal of nuclear medicine and molecular imaging, 42(2), pp.197-209. }\end{array}$ & 498 & 40.8 \\
\hline 45 & $\begin{array}{l}\text { Pibarot, P., Hahn, R.T., Weissman, N.J. and Monaghan, M.J., 2015. Assessment of paravalvular } \\
\text { regurgitation following TAVR: a proposal of unifying grading scheme. JACC: Cardiovascular } \\
\text { Imaging, 8(3), pp.340-360. }\end{array}$ & 106 & 40.5 \\
\hline 46 & $\begin{array}{l}\text { Le Bihan, D., 2013. Apparent diffusion coefficient and beyond: what diffusion MR imaging can tell } \\
\text { us about tissue structure. }\end{array}$ & 143 & 40.5 \\
\hline 47 & $\begin{array}{l}\text { Hutchison, R.M., Womelsdorf, T., Allen, E.A., Bandettini, P.A., Calhoun, V.D., Corbetta, M., Della } \\
\text { Penna, S., Duyn, J.H., Glover, G.H., Gonzalez-Castillo, J. and Handwerker, D.A., 2013. Dynamic } \\
\text { functional connectivity: promise, issues, and interpretations. Neuroimage, 80, pp.360-378. }\end{array}$ & 920 & 40.4 \\
\hline 48 & $\begin{array}{l}\text { Grayburn, P.A., Sannino, A. and Packer, M., 2019. Proportionate and disproportionate functional } \\
\text { mitral regurgitation: a new conceptual framework that reconciles the results of the MITRA-FR and } \\
\text { COAPT trials. JACC: Cardiovascular Imaging, 12(2), pp.353-362. }\end{array}$ & 68 & 39.7 \\
\hline 49 & Fleischmann, D. and Boas, F.E., 2011. Computed tomography—old ideas and new technology. & 153 & 38.7 \\
\hline 50 & $\begin{array}{l}\text { Avants, B.B., Tustison, N.J., Song, G., Cook, P.A., Klein, A. and Gee, J.C., 2011. A reproducible } \\
\text { evaluation of ANTs similarity metric performance in brain image registration. Neuroimage, 54(3), } \\
\text { pp.2033-2044. }\end{array}$ & 1130 & 38.1 \\
\hline 51 & $\begin{array}{l}\text { Blanke, P., Naoum, C., Dvir, D., Bapat, V., Ong, K., Muller, D., Cheung, A., Ye, J., Min, J.K., } \\
\text { Piazza, N. and Theriault-Lauzier, P., 2017. Predicting LVOT obstruction in transcatheter mitral } \\
\text { valve implantation: concept of the neo-LVOT. JACC: Cardiovascular Imaging, 10(4), pp.482-485. }\end{array}$ & 65 & 37.8 \\
\hline 52 & $\begin{array}{l}\text { Jacques, S.L., 2013. Optical properties of biological tissues: a review. Physics in Medicine \& } \\
\text { Biology, 58(11), p.R37. }\end{array}$ & 1317 & 37.2 \\
\hline 53 & $\begin{array}{l}\text { Murphy, K., Birn, R.M., Handwerker, D.A., Jones, T.B. and Bandettini, P.A., 2009. The impact of } \\
\text { global signal regression on resting state correlations: are anti-correlated networks } \\
\text { introduced?. Neuroimage, } 44(3) \text {, pp.893-905. }\end{array}$ & 1353 & 37.0 \\
\hline 54 & $\begin{array}{l}\text { Kanda, T., Ishii, K., Kawaguchi, H., Kitajima, K. and Takenaka, D., 2014. High signal intensity in } \\
\text { the dentate nucleus and globus pallidus on unenhanced T1-weighted MR images: relationship } \\
\text { with increasing cumulative dose of a gadolinium-based contrast material. Radiology, 270(3), } \\
\text { pp.834-841. }\end{array}$ & 541 & 36.3 \\
\hline 55 & $\begin{array}{l}\text { Patenaude, B., Smith, S.M., Kennedy, D.N. and Jenkinson, M., 2011. A Bayesian model of shape } \\
\text { and appearance for subcortical brain segmentation. Neuroimage, 56(3), pp.907-922. }\end{array}$ & 1065 & 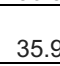 \\
\hline 56 & $\begin{array}{l}\text { Tessler, F.N., Middleton, W.D., Grant, E.G., Hoang, J.K., Berland, L.L., Teefey, S.A., Cronan, } \\
\text { J.J., Beland, M.D., Desser, T.S., Frates, M.C. and Hammers, L.W., 2017. ACR thyroid imaging, } \\
\text { reporting and data system (TI-RADS): white paper of the ACR TI-RADS committee. Journal of } \\
\text { the American college of radiology, 14(5), pp.587-595. }\end{array}$ & 259 & 35.3 \\
\hline 57 & $\begin{array}{l}\text { Kuo, M.D. and Jamshidi, N., 2014. Behind the numbers: decoding molecular phenotypes with } \\
\text { radiogenomics-guiding principles and technical considerations. Radiology, 270(2), pp.320-325. }\end{array}$ & 90 & 34.6 \\
\hline
\end{tabular}


medRxiv preprint doi: https://doi.org/10.1101/2020.11.14.20231944; this version posted November 17, 2020. The copyright holder for this preprint (which was not certified by peer review) is the author/funder, who has granted medRxiv a license to display the preprint in

It is made available under a CC-BY-NC-ND 4.0 International license .

\begin{tabular}{|c|c|c|c|}
\hline 58 & $\begin{array}{l}\text { Lakhani, P. and Sundaram, B., 2017. Deep learning at chest radiography: automated } \\
\text { classification of pulmonary tuberculosis by using convolutional neural } \\
\text { networks. Radiology, } 284(2) \text {, pp.574-582. }\end{array}$ & 251 & 34.2 \\
\hline 59 & $\begin{array}{l}\text { Madabhushi, A. and Lee, G., 2016. Image analysis and machine learning in digital pathology: } \\
\text { Challenges and opportunities. }\end{array}$ & 124 & 34.2 \\
\hline 60 & $\begin{array}{l}\text { Afshar-Oromieh, A., Zechmann, C.M., Malcher, A., Eder, M., Eisenhut, M., Linhart, H.G., Holland- } \\
\text { Letz, T., Hadaschik, B.A., Giesel, F.L., Debus, J. and Haberkorn, U., 2014. Comparison of PET } \\
\text { imaging with a } 68 \text { Ga-labelled PSMA ligand and } 18 \text { F-choline-based PET/CT for the diagnosis of } \\
\text { recurrent prostate cancer. European journal of nuclear medicine and molecular imaging, 41(1), } \\
\text { pp.11-20. }\end{array}$ & 506 & 33.9 \\
\hline 61 & $\begin{array}{l}\text { Bamber, J., Cosgrove, D., Dietrich, C.F., Fromageau, J., Bojunga, J., Calliada, F., Cantisani, V., } \\
\text { Correas, J.M., D'onofrio, M., Drakonaki, E.E. and Fink, M., 2013. EFSUMB guidelines and } \\
\text { recommendations on the clinical use of ultrasound elastography. Part 1: Basic principles and } \\
\text { technology. Ultraschall in der Medizin-European Journal of Ultrasound, 34(02), pp.169-184. }\end{array}$ & 523 & 33.6 \\
\hline 62 & $\begin{array}{l}\text { Cerqueira, M.D., Allman, K.C., Ficaro, E.P., Hansen, C.L., Nichols, K.J., Thompson, R.C., Van } \\
\text { Decker, W.A. and Yakovlevitch, M., } 2010 \text {. Recommendations for reducing radiation exposure in } \\
\text { myocardial perfusion imaging. Journal of nuclear cardiology, } 17(4), \text { pp. } 709-718 .\end{array}$ & 175 & 32.9 \\
\hline 63 & Fischl, B., 2012. FreeSurfer. Neuroimage, 62(2), pp.774-781. & 1797 & 32.8 \\
\hline 64 & $\begin{array}{l}\text { Klein, A., Andersson, J., Ardekani, B.A., Ashburner, J., Avants, B., Chiang, M.C., Christensen, } \\
\text { G.E., Collins, D.L., Gee, J., Hellier, P. and Song, J.H., 2009. Evaluation of } 14 \text { nonlinear } \\
\text { deformation algorithms applied to human brain MRI registration. Neuroimage, 46(3), pp.786-802. }\end{array}$ & 1188 & 32.5 \\
\hline 65 & $\begin{array}{l}\text { Kanda, T., Fukusato, T., Matsuda, M., Toyoda, K., Oba, H., Kotoku, J.I., Haruyama, T., Kitajima, } \\
\text { K. and Furui, S., 2015. Gadolinium-based contrast agent accumulates in the brain even in } \\
\text { subjects without severe renal dysfunction: evaluation of autopsy brain specimens with inductively } \\
\text { coupled plasma mass spectroscopy. Radiology, 276(1), pp.228-232. }\end{array}$ & 393 & 32.2 \\
\hline 66 & $\begin{array}{l}\text { Reuter, M., Schmansky, N.J., Rosas, H.D. and Fischl, B., 2012. Within-subject template } \\
\text { estimation for unbiased longitudinal image analysis. Neuroimage, 61(4), pp.1402-1418. }\end{array}$ & 851 & 31.6 \\
\hline 67 & $\begin{array}{l}\text { Kabasakal, E.D.L. and Kanmaz, M.H.B., 2014. } 68 \text { Ga-PSMA PET/CT imaging of metastatic clear } \\
\text { cell renal cell carcinoma. Eur. J. Nucl. Med. Mol. Imaging, 41, pp.1461-1462. }\end{array}$ & 82 & 31.5 \\
\hline 68 & $\begin{array}{l}\text { Jack Jr, C.R., 2012. Alzheimer disease: new concepts on its neurobiology and the clinical role } \\
\text { imaging will play. Radiology, 263(2), pp.344-361. }\end{array}$ & 117 & 31.3 \\
\hline 69 & $\begin{array}{l}\text { Woolrich, M.W., Jbabdi, S., Patenaude, B., Chappell, M., Makni, S., Behrens, T., Beckmann, C., } \\
\text { Jenkinson, M. and Smith, S.M., 2009. Bayesian analysis of neuroimaging data in } \\
\text { FSL. Neuroimage, 45(1), pp.S173-S186. }\end{array}$ & 1142 & 31.2 \\
\hline 70 & $\begin{array}{l}\text { Cosgrove, D., Piscaglia, F., Bamber, J., Bojunga, J., Correas, J.M., Gilja, O.H., Klauser, A.S., } \\
\text { Sporea, I., Calliada, F., Cantisani, V. and D’Onofrio, M., 2013. EFSUMB guidelines and } \\
\text { recommendations on the clinical use of ultrasound elastography. Part 2: Clinical } \\
\text { applications. Ultraschall in der Medizin-European Journal of Ultrasound, 34(03), pp.238-253. }\end{array}$ & 482 & 31.0 \\
\hline 71 & $\begin{array}{l}\text { Yan, C.G., Cheung, B., Kelly, C., Colcombe, S., Craddock, R.C., Di Martino, A., Li, Q., Zuo, X.N., } \\
\text { Castellanos, F.X. and Milham, M.P., 2013. A comprehensive assessment of regional variation in } \\
\text { the impact of head micromovements on functional connectomics. Neuroimage, 76, pp.183-201. }\end{array}$ & 703 & 30.9 \\
\hline 72 & $\begin{array}{l}\text { Zhang, H., Schneider, T., Wheeler-Kingshott, C.A. and Alexander, D.C., 2012. NODDI: practical } \\
\text { in vivo neurite orientation dispersion and density imaging of the human brain. Neuroimage, 61(4), } \\
\text { pp.1000-1016. }\end{array}$ & 831 & 30.8 \\
\hline 73 & $\begin{array}{l}\text { International Commission on Non-Ionizing Radiation Protection, 2010. Guidelines for limiting } \\
\text { exposure to time-varying electric and magnetic fields (1 Hz to } 100 \mathrm{kHz}) \text {. Health physics, 99(6), } \\
\text { pp.818-836. }\end{array}$ & 582 & 30.2 \\
\hline 74 & $\begin{array}{l}\text { Walsh, L., Shore, R., Auvinen, A., Jung, T. and Wakeford, R., 2014. Risks from CT scans-what } \\
\text { do recent studies tell us?. Journal of radiological protection, 34(1), p.E1. }\end{array}$ & 56 & 30.0 \\
\hline 75 & $\begin{array}{l}\text { Sotiras, A., Davatzikos, C. and Paragios, N., 2013. Deformable medical image registration: A } \\
\text { survey. IEEE transactions on medical imaging, 32(7), pp.1153-1190. }\end{array}$ & 552 & 29.9 \\
\hline 76 & $\begin{array}{l}\text { Clark, K., Vendt, B., Smith, K., Freymann, J., Kirby, J., Koppel, P., Moore, S., Phillips, S., Maffitt, } \\
\text { D., Pringle, M. and Tarbox, L., 2013. The Cancer Imaging Archive (TCIA): maintaining and } \\
\text { operating a public information repository. Journal of digital imaging, 26(6), pp.1045-1057. }\end{array}$ & 527 & 29.7 \\
\hline 77 & $\begin{array}{l}\text { Wu, C.C., Maher, M.M. and Shepard, J.A.O., 2011. Complications of CT-guided percutaneous } \\
\text { needle biopsy of the chest: prevention and management. American Journal of } \\
\text { Roentgenology, 196(6), pp.W678-W682. }\end{array}$ & 117 & 29.6 \\
\hline 78 & $\begin{array}{l}\text { Smith, S.M., Miller, K.L., Salimi-Khorshidi, G., Webster, M., Beckmann, C.F., Nichols, T.E., } \\
\text { Ramsey, J.D. and Woolrich, M.W., 2011. Network modelling methods for } \\
\text { FMRI. Neuroimage, 54(2), pp.875-891. }\end{array}$ & 873 & 29.4 \\
\hline 79 & $\begin{array}{l}\text { Horn, A., Li, N., Dembek, T.A., Kappel, A., Boulay, C., Ewert, S., Tietze, A., Husch, A., Perera, T., } \\
\text { Neumann, W.J. and Reisert, M., 2019. Lead-DBS v2: Towards a comprehensive pipeline for } \\
\text { deep brain stimulation imaging. Neuroimage, 184, pp.293-316. }\end{array}$ & 50 & 29.3 \\
\hline 80 & $\begin{array}{l}\text { Piscaglia, F., Nolsøe, C., Dietrich, C.A., Cosgrove, D.O., Gilja, O.H., Nielsen, M.B., Albrecht, T., } \\
\text { Barozzi, L., Bertolotto, M., Catalano, O. and Claudon, M., 2012. The EFSUMB Guidelines and } \\
\text { Recommendations on the Clinical Practice of Contrast Enhanced Ultrasound (CEUS): update } \\
2011 \text { on non-hepatic applications. Ultraschall in der Medizin-European Journal of } \\
\text { Ultrasound, 33(01), pp.33-59. }\end{array}$ & 506 & 29.3 \\
\hline 81 & $\begin{array}{l}\text { Boellaard, R., O'Doherty, M.J., Weber, W.A., Mottaghy, F.M., Lonsdale, M.N., Stroobants, S.G., } \\
\text { Oyen, W.J., Kotzerke, J., Hoekstra, O.S., Pruim, J. and Marsden, P.K., 2010. FDG PET and } \\
\text { PET/CT: EANM procedure guidelines for tumour PET imaging: version 1.0. European journal of } \\
\text { nuclear medicine and molecular imaging, } 37(1), \text { p.181. }\end{array}$ & 730 & 29.2 \\
\hline 82 & $\begin{array}{l}\text { Afshar-Oromieh, A., Haberkorn, U., Eder, M., Eisenhut, M. and Zechmann, C.M., 2012. [68 Ga] } \\
\text { Gallium-labelled PSMA ligand as superior PET tracer for the diagnosis of prostate cancer: } \\
\text { comparison with } 18 \text { F-FECH. European journal of nuclear medicine and molecular } \\
\text { imaging, 39(6), pp.1085-1086. }\end{array}$ & 109 & 29.2 \\
\hline 83 & $\begin{array}{l}\text { Zalesky, A. and Breakspear, M., 2015. Towards a statistical test for functional connectivity } \\
\text { dynamics. Neuroimage, } 114, \text { pp.466-470. }\end{array}$ & 102 & 29.1 \\
\hline 84 & $\begin{array}{l}\text { Lamm, C., Decety, J. and Singer, T., 2011. Meta-analytic evidence for common and distinct } \\
\text { neural networks associated with directly experienced pain and empathy for } \\
\text { pain. Neuroimage, 54(3), pp.2492-2502. }\end{array}$ & 857 & 28.9 \\
\hline 85 & $\begin{array}{l}\text { Giesel, F.L., Knorr, K., Spohn, F., Will, L., Maurer, T., Flechsig, P., Neels, O., Schiller, K., Amaral, } \\
\text { H., Weber, W.A. and Haberkorn, U., 2019. Detection efficacy of 18F-PSMA-1007 PET/CT in } 251\end{array}$ & 42 & 28.9 \\
\hline
\end{tabular}


medRxiv preprint doi: https://doi.org/10.1101/2020.11.14.20231944; this version posted November 17, 2020. The copyright holder for this preprint (which was not certified by peer review) is the author/funder, who has granted medRxiv a license to display the preprint in It is made available under a CC-BY-NC-ND 4.0 International license .

\begin{tabular}{|c|c|c|c|}
\hline & $\begin{array}{l}\text { patients with biochemical recurrence of prostate cancer after radical prostatectomy. Journal of } \\
\text { Nuclear Medicine, } 60(3) \text {, pp.362-368. }\end{array}$ & & \\
\hline 86 & $\begin{array}{l}\text { Naidich, D.P., Bankier, A.A., MacMahon, H., Schaefer-Prokop, C.M., Pistolesi, M., Goo, J.M., } \\
\text { Macchiarini, P., Crapo, J.D., Herold, C.J., Austin, J.H. and Travis, W.D., 2013. Recommendations } \\
\text { for the management of subsolid pulmonary nodules detected at CT: a statement from the } \\
\text { Fleischner Society. Radiology, 266(1), pp.304-317. }\end{array}$ & 510 & 28.8 \\
\hline 87 & $\begin{array}{l}\text { Anthimopoulos, M., Christodoulidis, S., Ebner, L., Christe, A. and Mougiakakou, S., 2016. Lung } \\
\text { pattern classification for interstitial lung diseases using a deep convolutional neural } \\
\text { network. IEEE transactions on medical imaging, 35(5), pp.1207-1216. }\end{array}$ & 306 & 28.7 \\
\hline 88 & $\begin{array}{l}\text { Darcourt, J., Booij, J., Tatsch, K., Varrone, A., Vander Borght, T., Kapucu, Ö.L., Någren, K., } \\
\text { Nobili, F., Walker, Z. and Van Laere, K., 2010. EANM procedure guidelines for brain } \\
\text { neurotransmission SPECT using } 123 \text { I-labelled dopamine transporter ligands, version } \\
\text { 2. European journal of nuclear medicine and molecular imaging, 37(2), pp.443-450. }\end{array}$ & 150 & 28.5 \\
\hline 89 & $\begin{array}{l}\text { Satterthwaite, T.D., Elliott, M.A., Gerraty, R.T., Ruparel, K., Loughead, J., Calkins, M.E., Eickhoff, } \\
\text { S.B., Hakonarson, H., Gur, R.C., Gur, R.E. and Wolf, D.H., 2013. An improved framework for } \\
\text { confound regression and filtering for control of motion artifact in the preprocessing of resting-state } \\
\text { functional connectivity data. Neuroimage, } 64, \text { pp.240-256. }\end{array}$ & 645 & 28.4 \\
\hline 90 & $\begin{array}{l}\text { Power, J.D., Barnes, K.A., Snyder, A.Z., Schlaggar, B.L. and Petersen, S.E., 2013. Steps toward } \\
\text { optimizing motion artifact removal in functional connectivity MRI; a reply to } \\
\text { Carp. Neuroimage, } 76 \text {. }\end{array}$ & 173 & 28.3 \\
\hline 91 & $\begin{array}{l}\text { Bartra, O., McGuire, J.T. and Kable, J.W., 2013. The valuation system: a coordinate-based meta- } \\
\text { analysis of BOLD fMRI experiments examining neural correlates of subjective } \\
\text { value. Neuroimage, } 76, \text { pp.412-427. }\end{array}$ & 637 & 28.0 \\
\hline 92 & $\begin{array}{l}\text { Christ, A., Kainz, W., Hahn, E.G., Honegger, K., Zefferer, M., Neufeld, E., Rascher, W., Janka, } \\
\text { R., Bautz, W., Chen, J. and Kiefer, B., 2009. The Virtual Family-development of surface-based } \\
\text { anatomical models of two adults and two children for dosimetric simulations. Physics in Medicine } \\
\text { \& Biology, 55(2), p.N23. }\end{array}$ & 767 & 28.0 \\
\hline 93 & $\begin{array}{l}\text { Lammer, J., Malagari, K., Vogl, T., Pilleul, F., Denys, A., Watkinson, A., Pitton, M., Sergent, G., } \\
\text { Pfammatter, T., Terraz, S. and Benhamou, Y., 2010. Prospective randomized study of } \\
\text { doxorubicin-eluting-bead embolization in the treatment of hepatocellular carcinoma: results of the } \\
\text { PRECISION V study. Cardiovascular and interventional radiology, 33(1), pp.41-52. }\end{array}$ & 737 & 27.9 \\
\hline 94 & $\begin{array}{l}\text { Setio, A.A.A., Ciompi, F., Litjens, G., Gerke, P., Jacobs, C., Van Riel, S.J., Wille, M.M.W., } \\
\text { Naqibullah, M., Sánchez, C.I. and van Ginneken, B., 2016. Pulmonary nodule detection in CT } \\
\text { images: false positive reduction using multi-view convolutional networks. IEEE transactions on } \\
\text { medical imaging, 35(5), pp.1160-1169. }\end{array}$ & 296 & 27.8 \\
\hline 95 & $\begin{array}{l}\text { Kumar, V., Gu, Y., Basu, S., Berglund, A., Eschrich, S.A., Schabath, M.B., Forster, K., Aerts, } \\
\text { H.J., Dekker, A., Fenstermacher, D. and Goldgof, D.B., 2012. Radiomics: the process and the } \\
\text { challenges. Magnetic resonance imaging, 30(9), pp.1234-1248. }\end{array}$ & 557 & 27.7 \\
\hline 96 & $\begin{array}{l}\text { Mazurowski, M.A., 2015. Radiogenomics: what it is and why it is important. Journal of the } \\
\text { American College of Radiology, 12(8), pp.862-866. }\end{array}$ & 71 & 27.5 \\
\hline 97 & $\begin{array}{l}\text { Greve, D.N. and Fischl, B., 2009. Accurate and robust brain image alignment using boundary- } \\
\text { based registration. Neuroimage, 48(1), pp.63-72. }\end{array}$ & 1002 & 27.4 \\
\hline 98 & $\begin{array}{l}\text { Villemagne, V.L., Klunk, W.E., Mathis, C.A., Rowe, C.C., Brooks, D.J., Hyman, B.T., Ikonomovic, } \\
\text { M.D., Ishii, K., Jack, C.R., Jagust, W.J. and Johnson, K.A., 2012. A } \text { Imaging: feasible, pertinent, } \\
\text { and vital to progress in Alzheimer's disease. }\end{array}$ & 102 & 27.3 \\
\hline 99 & $\begin{array}{l}\text { Marinescu, M.A., Löffler, A.I., Ouellette, M., Smith, L., Kramer, C.M. and Bourque, J.M., } 2015 . \\
\text { Coronary microvascular dysfunction, microvascular angina, and treatment strategies. JACC: } \\
\text { Cardiovascular Imaging, 8(2), pp.210-220. }\end{array}$ & 71 & 27.1 \\
\hline 100 & $\begin{array}{l}\text { Kooi, T., Litjens, G., Van Ginneken, B., Gubern-Mérida, A., Sánchez, C.I., Mann, R., den Heeten, } \\
\text { A. and Karssemeijer, N., 2017. Large scale deep learning for computer aided detection of } \\
\text { mammographic lesions. Medical image analysis, 35, pp.303-312. }\end{array}$ & 215 & 27.0 \\
\hline
\end{tabular}


medRxiv preprint doi: https://doi.org/10.1101/2020.11.14.20231944; this version posted November $17,2020$. The copyright holder for this preprint (which was not certified by peer review) is the author/funder, who has granted medRxiv a license to display the preprint in It is made available under a CC-BY-NC-ND 4.0 International license .

Table 3

\begin{tabular}{ccc}
\hline $\begin{array}{c}\text { Year of } \\
\text { publication }\end{array}$ & $\begin{array}{c}\text { No. of articles in } \\
\text { highest-cited list }\end{array}$ & $\begin{array}{c}\text { No. of articles in } \\
\text { highest-CNCI list }\end{array}$ \\
\hline 2009 & 22 & 7 \\
\hline 2010 & 22 & 10 \\
\hline 2011 & 8 & 9 \\
\hline 2012 & 18 & 15 \\
\hline 2013 & 11 & 16 \\
\hline 2014 & 5 & 7 \\
\hline 2015 & 6 & 12 \\
\hline 2016 & 5 & 10 \\
\hline 2017 & 3 & 8 \\
\hline 2018 & 0 & 3 \\
\hline 2020 & 0 & 3 \\
\hline
\end{tabular}


medRxiv preprint doi: https://doi.org/10.1101/2020.11.14.20231944; this version posted November 17, 2020. The copyright holder for this preprint (which was not certified by peer review) is the author/funder, who has granted medRxiv a license to display the preprint in

It is made available under a CC-BY-NC-ND 4.0 International license .

Table 4

\begin{tabular}{|c|c|c|}
\hline Journal & $\begin{array}{l}\text { No. of articles in } \\
\text { highest-cited list }\end{array}$ & $\begin{array}{l}\text { No. of articles in } \\
\text { highest-CNCI list }\end{array}$ \\
\hline Neurolmage & 51 & 30 \\
\hline $\begin{array}{l}\text { IEEE Transactions on Medical } \\
\text { Imaging }\end{array}$ & 6 & 11 \\
\hline Human Brain Mapping & 5 & 0 \\
\hline Magnetic Resonance in Medicine & 5 & 0 \\
\hline Medical Image Analysis & 4 & 5 \\
\hline Radiology & 4 & 13 \\
\hline $\begin{array}{l}\text { European Journal of Nuclear } \\
\text { Medicine }\end{array}$ & 3 & 8 \\
\hline $\begin{array}{l}\text { European Journal of } \\
\text { Echocardiography }\end{array}$ & 2 & 0 \\
\hline Journal of Biomedical Optics & 2 & 0 \\
\hline Magnetic Resonance Imaging & 2 & 2 \\
\hline Physics in Medicine and Biology & 2 & 2 \\
\hline Ultraschall In Der Medizen & 2 & 3 \\
\hline $\begin{array}{l}\text { American Journal of } \\
\text { Roentgenology }\end{array}$ & 1 & 1 \\
\hline $\begin{array}{l}\text { Cardiovascular and Interventional } \\
\text { Radiology }\end{array}$ & 1 & 1 \\
\hline $\begin{array}{l}\text { European Heart Journal - } \\
\text { Cardiology }\end{array}$ & 1 & 1 \\
\hline European Radiology & 1 & 2 \\
\hline Health Physics & 1 & 2 \\
\hline $\begin{array}{l}\text { International Journal of Computer } \\
\text { Assisted Radiology and Surgery }\end{array}$ & 1 & 0 \\
\hline $\begin{array}{l}\text { International Journal of Radiation } \\
\text { Oncology - Biology - Physics }\end{array}$ & 1 & 0 \\
\hline Journal of Digital Imaging & 1 & 1 \\
\hline Journal of Nuclear Medicine & 1 & 4 \\
\hline $\begin{array}{l}\text { Journal of the American Society of } \\
\text { Echocardiography }\end{array}$ & 1 & 0 \\
\hline Medical Physics & 1 & 0 \\
\hline NMR in Biomedicine & 1 & 0 \\
\hline JACC - Cardiovascular Imaging & 0 & 6 \\
\hline Journal of Magnetic Resonance & 0 & 1 \\
\hline Journal of Nuclear Cardiology & 0 & 1 \\
\hline Journal of Radiological Protection & 0 & 1 \\
\hline $\begin{array}{l}\text { Journal of the American College of } \\
\text { Radiology }\end{array}$ & 0 & 2 \\
\hline Radiation Protection Dosimetry & 0 & 1 \\
\hline Radiographics & 0 & 1 \\
\hline $\begin{array}{l}\text { Ultrasound in Obstetrics and } \\
\text { Gynaecology }\end{array}$ & 0 & 1 \\
\hline
\end{tabular}


medRxiv preprint doi: https://doi.org/10.1101/2020.11.14.20231944; this version posted November $17,2020$. The copyright holder for this preprint (which was not certified by peer review) is the author/funder, who has granted medRxiv a license to display the preprint in It is made available under a CC-BY-NC-ND 4.0 International license .

Table 5.

\begin{tabular}{lcc}
\hline \multicolumn{1}{c}{ Radiological Subspecialty } & $\begin{array}{c}\text { No. of articles in } \\
\text { highest-cited list }\end{array}$ & $\begin{array}{c}\text { No. of articles in } \\
\text { highest-CNCI list }\end{array}$ \\
\hline Neuroradiology & 68 & 41 \\
\hline Cardiac & 4 & 7 \\
\hline Nuclear Imaging & 4 & 7 \\
\hline Interventional & 1 & 2 \\
\hline Genitourinary & 1 & 5 \\
\hline Respiratory & 1 & 6 \\
\hline Abdominal & 0 & 2 \\
\hline Breast & 0 & 1 \\
\hline Mixed & 1 & 2 \\
\hline Safety & 5 & 6 \\
\hline Miscellaneous & 15 & 21 \\
\hline \multicolumn{1}{c}{ Primary Modality } & & 40 \\
\hline MR Imaging & 64 & 7 \\
\hline US & 7 & 12 \\
\hline CT & 4 & 13 \\
\hline Nuclear Imaging & 4 & 1 \\
\hline Interventional & 1 & 1 \\
\hline Breast imaging & 0 & 1 \\
\hline Radiography & 0 & 9 \\
\hline Mixed modality & 8 & 16 \\
\hline Other & 12 & \\
\hline & & \\
\hline
\end{tabular}


medRxiv preprint doi: https://doi.org/10.1101/2020.11.14.20231944; this version posted November 17, 2020. The copyright holder for this preprint (which was not certified by peer review) is the author/funder, who has granted medRxiv a license to display the preprint in It is made available under a CC-BY-NC-ND 4.0 International license

\subsection{Figures}

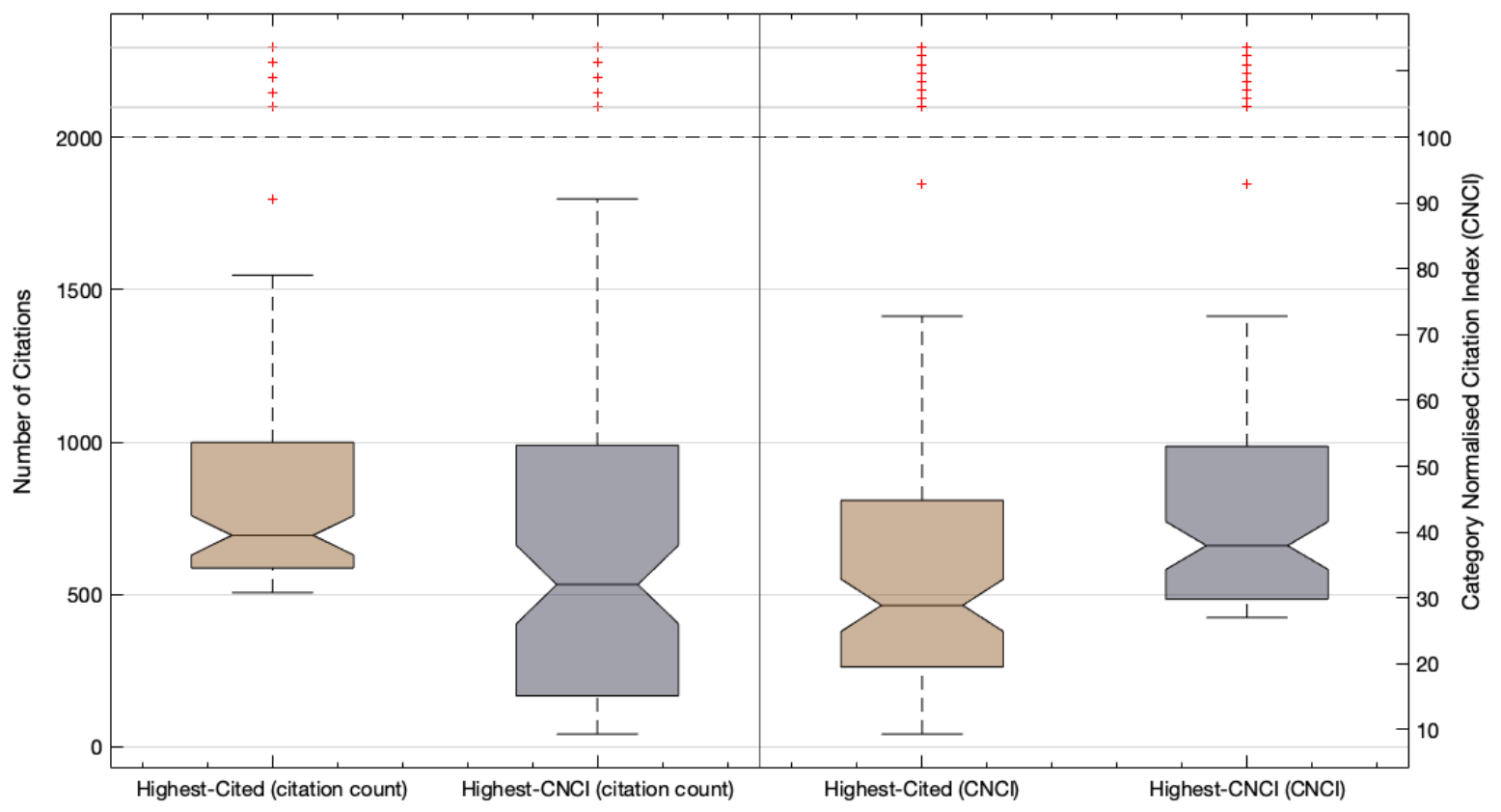

